CRYSTALLOGRAPHIC COMMUNICATIONS

ISSN 2056-9890

\section{Crystal structure, Hirshfeld surface analysis and computational study of a rhodamine B-salicyl- aldehyde Schiff base derivative}

\author{
Songwut Suramitr, ${ }^{a}$ Jitpinan Teanwarawat, ${ }^{\text {a }}$ Nuttapong Ithiapa, ${ }^{a}$ Worawat \\ Wattanathanab and Anwaraporn Suramitr ${ }^{\mathrm{C} *}$
}

Received 24 March 2020

Accepted 28 May 2020

Edited by O. Blacque, University of Zürich, Switzerland

Keywords: crystal structure; rhodamine B derivative; Hirshfeld surface; computational study.

CCDC reference: 2006371

Supporting information: this article has supporting information at journals.iucr.org/e

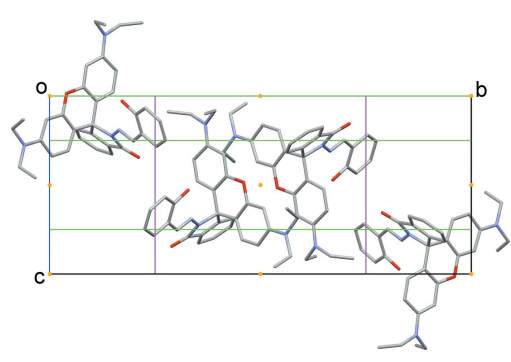

\section{Chemical context}

Rhodamine B derivatives are employed extensively as molecular probes in the study of complex biological systems because of their high absorption coefficients, high fluorescence quantum yields and long-wavelength absorptions and emissions (Bao et al., 2013; Biswal \& Bag, 2013). On the basis of the spirolactam/ring-opened amide equilibrium of rhodamine, several fluorescence-based sensing systems for metal ions have been developed. Most of the reported sensors based on rhodamine B derivatives are fluorescent chemosensors for metal ion detection (Quang \& Kim, 2010; Kim et al., 2008; Kwon et al., 2005; Liu et al., 2013; Ni et al., 2013). A rhodamine 
B derivative is usually used as a chemosensor because of its good photophysical properties, sensitivity, the low cost of chemical reagents and the ease of modifying its structure. Rhodamine B derivatives have naked-eye detection and show off-on fluorescent property when reacting with metal ions.<smiles>CCN(CC)c1ccc2c(c1)Oc1cc(N(CC)CC)ccc1C21c2ccccc2C(=O)N1/N=C/c1ccccc1O</smiles>

\section{Structural commentary}

Fig. 1 shows the molecular structure of the title compound (rhodamine B - salicylaldehyde derivative, RbSa) together with the atomic labelling scheme. The title compound crystallizes in the monoclinic space group $P 2_{1} / \mathrm{c}$, and the asymmetric unit contains a single molecule in a general position. The molecule can be seen as having two distinct parts sharing a central quaternary carbon atom. The atoms in the xanthene moiety, namely C5-C10, O1, C11-C17, are almost coplanar, as seen from the r.m.s. deviation of $0.0411 \AA$ (Fig. 2a). The atoms $\mathrm{C} 11, \mathrm{C} 22-\mathrm{C} 28, \mathrm{O} 2, \mathrm{~N} 3$ and $\mathrm{N} 4$ of the isoindole unit are also nearly coplanar with an r.m.s. deviation of $0.0545 \AA$ (Fig. $2 b$ ). These two planes are almost perpendicular to each other, the dihedral angle between their mean planes being $87.71(2)^{\circ}$ (Fig. 2c). The four ethyl groups present in the molecule point out of the xanthene plane and are on the same side of the plane; the corresponding out-of-plane torsion angles $\mathrm{C} 16-$ $\mathrm{N} 2-\mathrm{C} 19-\mathrm{C} 18, \mathrm{C} 16-\mathrm{N} 2-\mathrm{C} 21-\mathrm{C} 20, \mathrm{C} 5-\mathrm{N} 1-\mathrm{C} 2-\mathrm{C} 1$ and

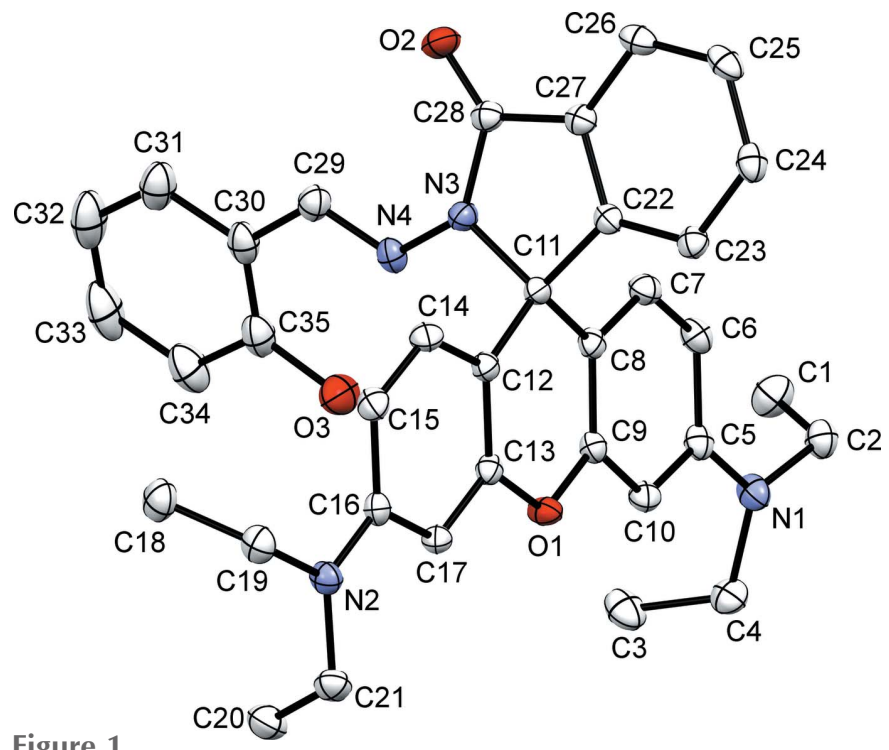

Figure 1

The molecular structure of RbSa, showing the atom-labelling scheme. Displacement ellipsoids are drawn at the $50 \%$ probability level. The nonIUPAC atom labelling is for the convenience of discussion.
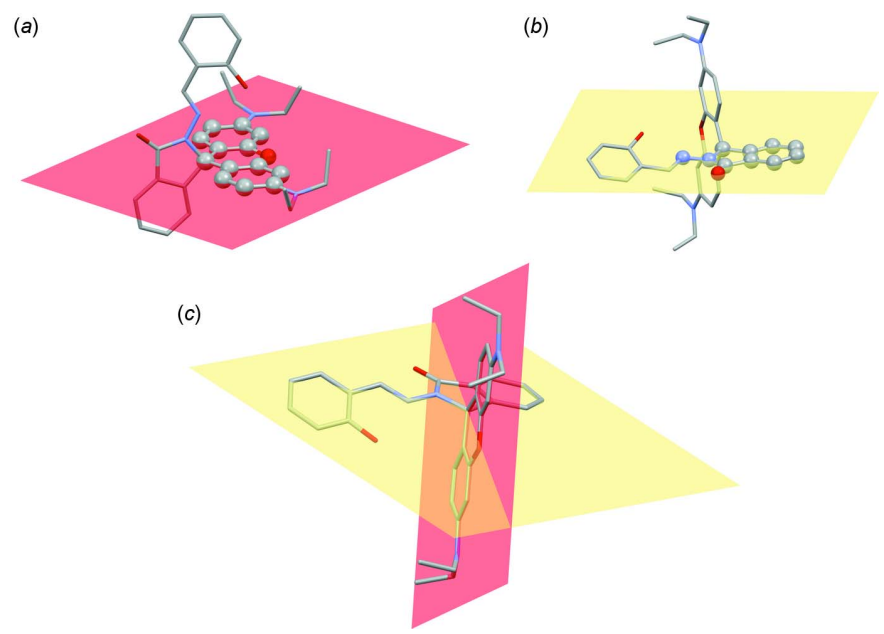

Figure 2

(a) The xanthene plane that is a mean plane constructed from 14 atoms, namely $\mathrm{C} 5, \mathrm{C} 6-\mathrm{C} 10, \mathrm{O} 1, \mathrm{C} 11-\mathrm{C} 17 .(b)$ a mean plane constructed from 11 atoms, namely $\mathrm{C} 11, \mathrm{C} 22-\mathrm{C} 28, \mathrm{O} 2, \mathrm{~N} 3$, and N4. (c) View of the molecule showing that planes $(a)$ and $(b)$ are roughly perpendicular to each other.

$\mathrm{C} 5-\mathrm{N} 1-\mathrm{C} 4-\mathrm{C} 3$ are $73.76(15),-79.52(15),-86.26(15)$ and $65.09(16)^{\circ}$, respectively.

The major tautomer of the rhodamine B - salicylaldehyde Schiff-base derivative is usually the enol form for compounds having hydroxy and azamethylene groups attached to the benzene ring in the ortho positions (Veranitisagul et al., 2012; Wattanathana et al., 2012, 2016). Similarly, our title compound appears to be in its enol form. The corresponding $\mathrm{H}$ atom was located and freely refined at a distance of 1.02 (3) $\AA$ from the $\mathrm{O}$ atom and 1.72 (2) A from the $\mathrm{N}$ atom (Table 1, Fig. 3). The strong intramolecular $\mathrm{O}-\mathrm{H} \cdots \mathrm{N}$ hydrogen bond bridging the hydroxyl group and its neighbouring nitrogen atom forms an $S(6)$ graph-set motif involving atoms $\mathrm{N} 4, \mathrm{H} 3, \mathrm{O} 3, \mathrm{C} 35, \mathrm{C} 30$

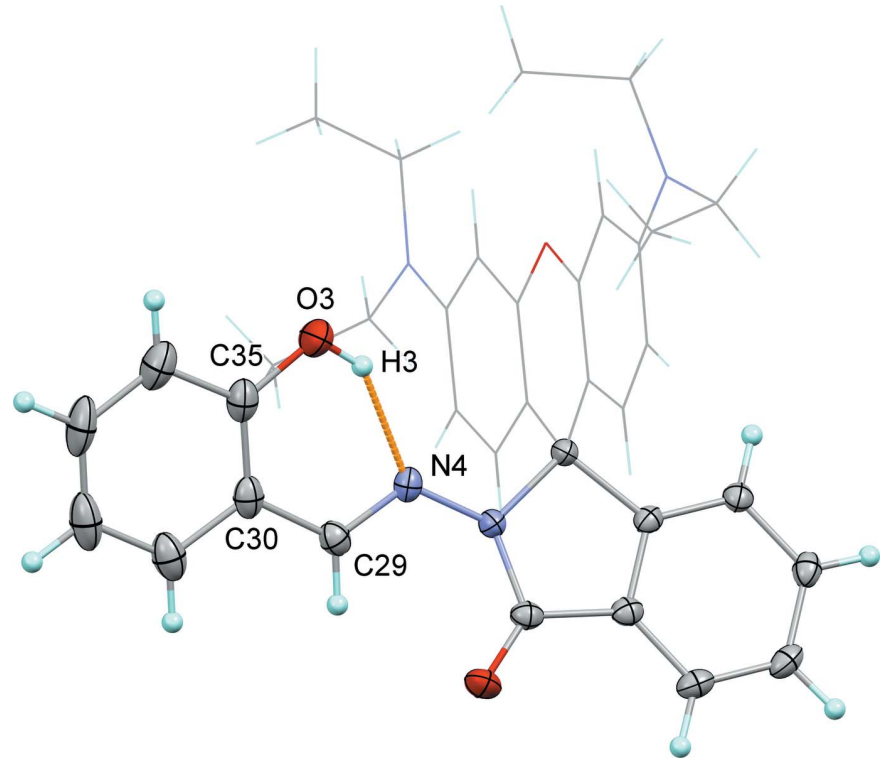

Figure 3

A view of molecule illustrating the $S(6)$ ring of the intramolecular hydrogen bond constructed from the N4-C29-C30-C35-O3-H3 synthon. 


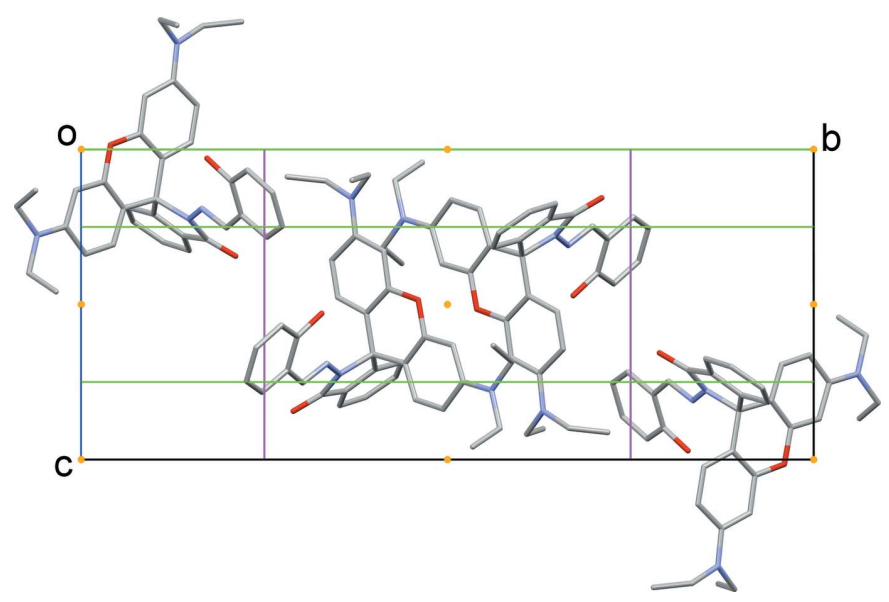

Figure 4

The unit cell and molecular packing in the title compound with the unitcell contents projecting down the [100] direction. The orange dots represent inversion centres and the green and magenta lines represent glide planes and twofold axes, respectively.

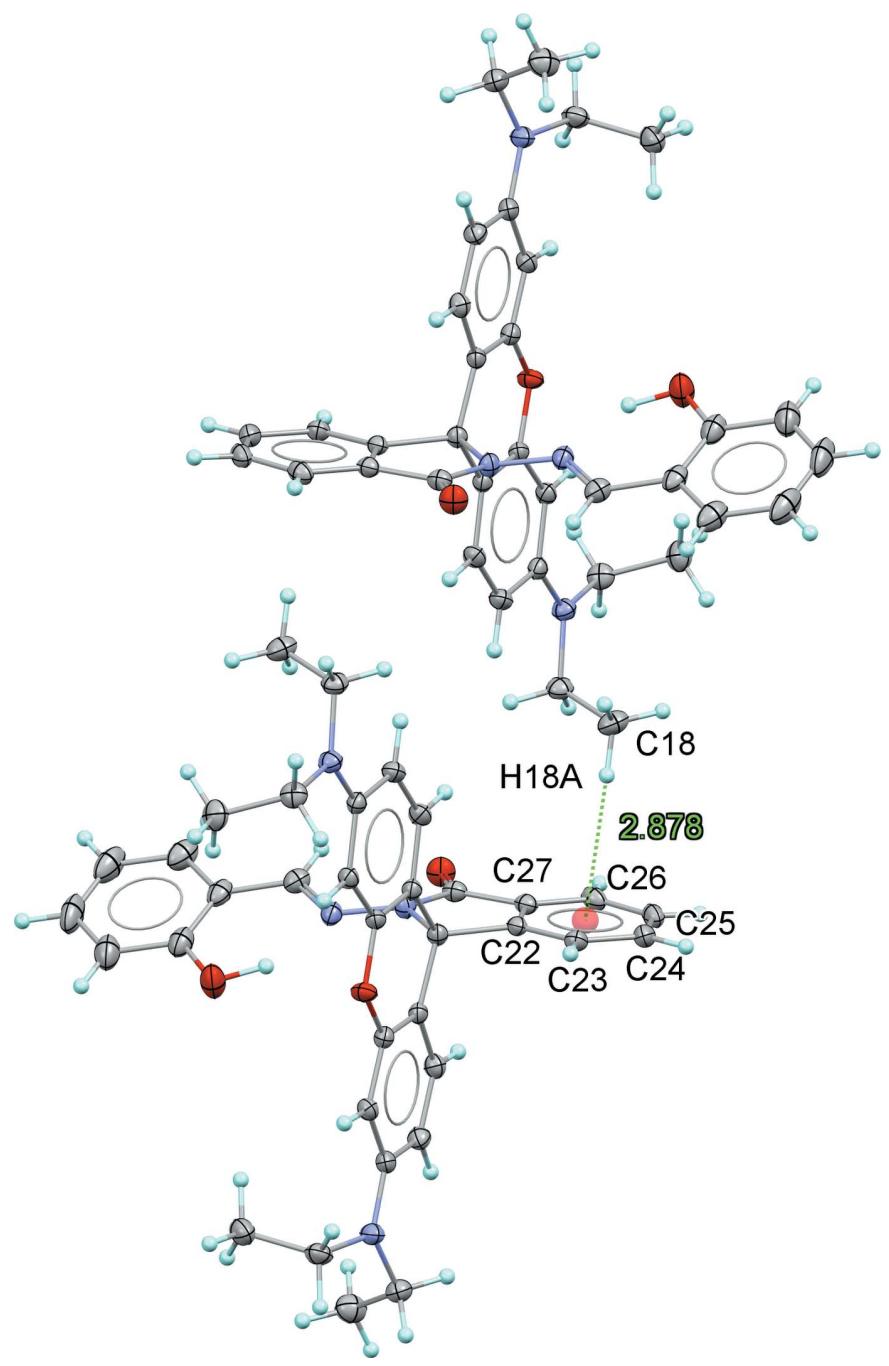

Figure 5

A view of the crystal packing showing $\mathrm{C}-\mathrm{H} \cdots \pi$ interactions between $\mathrm{C} 18-\mathrm{H} 18 A$ and the $\mathrm{C} 22-\mathrm{C} 27$ ring of the isoindole unit.
Table 1

Hydrogen-bond geometry $\left(\AA,^{\circ}\right)$.

$C g$ is the centroid of the $\mathrm{C} 22-\mathrm{C} 27$ ring.

\begin{tabular}{lllll}
\hline$D-\mathrm{H} \cdots A$ & $D-\mathrm{H}$ & $\mathrm{H} \cdots A$ & $D \cdots A$ & $D-\mathrm{H} \cdots A$ \\
\hline $\mathrm{C} 31-\mathrm{H} 31 \cdots \mathrm{O} 3^{\mathrm{i}}$ & 0.95 & 2.77 & $3.4737(19)$ & 131 \\
$\mathrm{O} 3-\mathrm{H} 3 \cdots \mathrm{N} 4$ & $1.02(3)$ & $1.72(2)$ & $2.6276(15)$ & $145(2)$ \\
$\mathrm{C} 18-\mathrm{H} 18 A \cdots C g^{\mathrm{ii}}$ & 0.98 & 2.88 & $3.8191(15)$ & 161 \\
\hline
\end{tabular}

Symmetry codes: (i) $x,-y+\frac{3}{2}, z-\frac{1}{2}$; (ii) $-x+1,-y+1,-z$.

and C29 and stabilizes a rigid configuration that can partially inhibit the rotation of the phenyl ring about the $\mathrm{N}-\mathrm{N}$ bond.

\section{Supramolecular features}

Besides the intramolecular $\mathrm{O}-\mathrm{H} \cdots \mathrm{N}$ hydrogen bond, the title molecules form $\mathrm{C} 31-\mathrm{H} 31 \cdots \mathrm{O} 3^{\mathrm{i}}$ interactions [symmetry code: (i) $x,-y+\frac{3}{2}, z-\frac{1}{2}$ ] between two neighbouring $\mathrm{RbSa}$ molecules related by an inversion center (Fig. 4). The

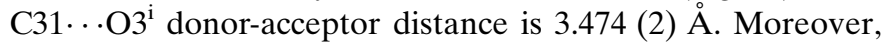
$\mathrm{C}-\mathrm{H} \cdots \pi$ interactions are observed between $\mathrm{C} 18-\mathrm{H} 18 \mathrm{~A}$ and the benzene ring (C22-C27) of the isoindole unit (Fig. 5). Within the crystal structure, the RbSa molecules aggregate into infinite molecular chains in an end-to-end packing mode along the [100] direction. No $\pi-\pi$ interactions are observed in the crystal structure as the shortest distance between ring centroids is greater than $4 \AA$.

\section{Hirshfeld surface analysis}

The intermolecular interactions in the crystal of the title compound were investigated and visualized by performing a Hirshfeld surface (HS) analysis (Hirshfeld, 1977; Spackman \& Jayatilaka, 2009) using Crystal Explorer 17.5 software (Turner et al. 2017). The HS plotted over $d_{\text {norm }}$ in the range -0.1732 to 1.4064 a.u. is shown in Fig. 6. Fig. 7 shows the full twodimensional fingerprint plot (McKinnon et al., 2007) and those delineated into the major contacts: $\mathrm{H} \cdots \mathrm{H}(61.5 \%), \mathrm{H} \cdots \mathrm{C} /$ $\mathrm{C} \cdot \mathrm{H}(20.3 \%), \mathrm{H} \cdots \mathrm{O} / \mathrm{O} \cdots \mathrm{H}(11.7 \%)$, and $\mathrm{H} \cdots \mathrm{N} / \mathrm{N} \cdots \mathrm{H}$ (1.9\%) for which $d_{\mathrm{e}}+d_{\mathrm{i}} \sim 2.0,3.0,2.8$ and $3.4 \AA$, respectively. The other contacts are negligible with individual contributions of less than $1 \%$ and a sum of less than $5 \%$.
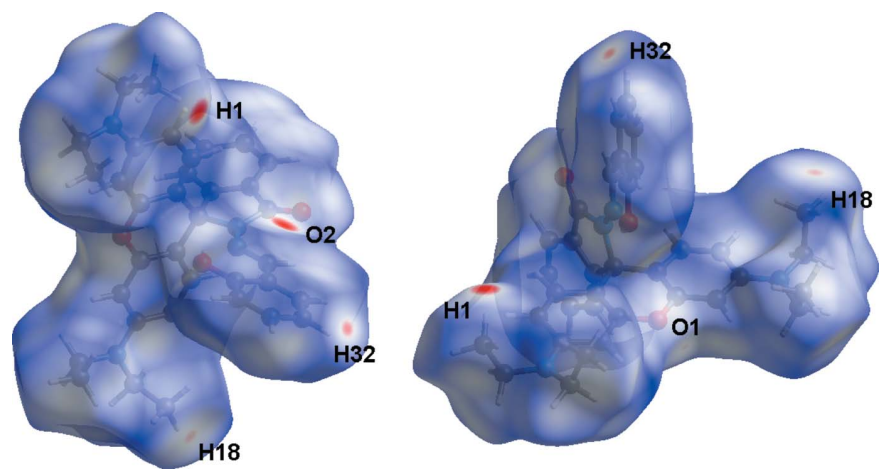

Figure 6

Two views of the three-dimensional Hirshfeld surface of the title compound plotted over $d_{\text {norm }}$ in the range -0.1732 to 1.4064 a.u. 


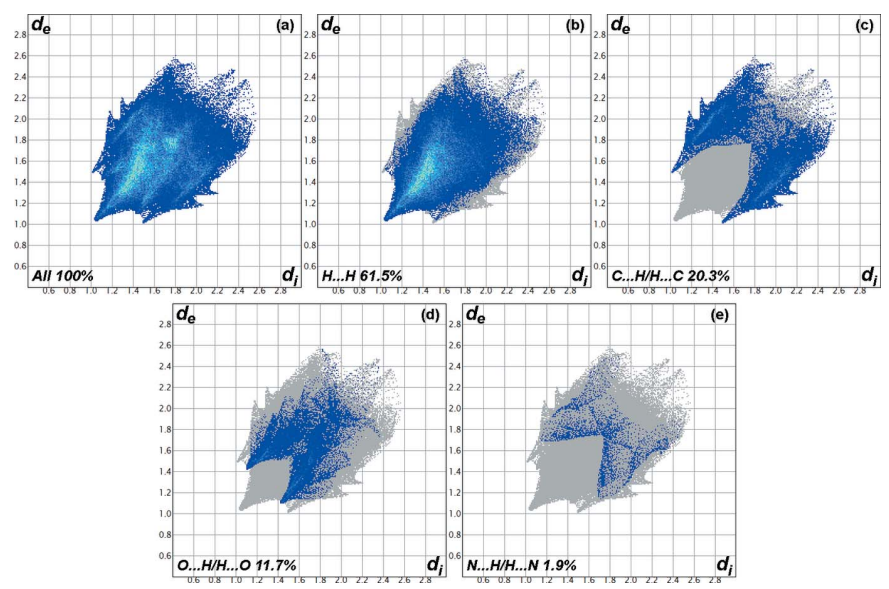

Figure 7

The full two-dimensional fingerprint plots for the title compound, showing $(a)$ all interactions and those delineated into $(b) \mathrm{H} \cdots \mathrm{H},(c)$ $\mathrm{C} \cdots \mathrm{H} / \mathrm{H} \cdots \mathrm{C},(d) \mathrm{O} \cdots \mathrm{H} / \mathrm{H} \cdots \mathrm{O}$, and $(e) \mathrm{N} \cdots \mathrm{H} / \mathrm{H} \cdots \mathrm{N}$ interactions.

\section{Database survey}

A search of the Cambridge Structural Database (CSD version 5.41, November 2019 + one update; Groom et al., 2016) shows that the crystal structures of many compounds having rhodamine $\mathrm{B}$ as a core have been reported. The structural diversity of rhodamine $\mathrm{B}$ derivatives results from the fact that the different functional groups in the molecules can be tuned. For example, the carboxylic functional group can be converted to ester functional groups such as methyl ester derivatives (I) (ROKNOU; Fun et al., 1997) and (II) (QIMMII; Adhikesavalu et al., 2001), ethyl ester derivatives (III) (QIMMEE; Adhikesavalu et al., 2001) and cyclic lactones (IV) (FUFTIJ; Kvick et al., 2000). In our case, the carboxylic acid functional group is sequentially transformed into a cyclic lactam with a hydrazone side chain. The counter-anions are the other key factor in the crystal structures of rhodamine B derivatives. Mizuguchi (2008) reported the crystal structure of the ethyl gallate salt at $93 \mathrm{~K}$ (PIHJIA01), and Venkatraman et al. (2008) published a new derivative with the hexachloridostannate(IV) anion, RISQIU. Moreover, rhodamine B derivatives can be used as a ligand for many metal cations to form coordination complexes such as the cadmium complex (V) (IKISUQ; Qu et al., 2001).

\section{Synthesis and crystallization}

The reagents were purchased from commercial suppliers and used without further purification: rhodamine B (Fluka Chemicals), hydrazine hydrate (Across Organics), salicyaldehyde (Sigma-Aldrich), hydrochloric acid (Valchem), ammonium hydroxide (Mallinckrodt Chemicals) and sodium hydroxide (RCI Labscan). Solvents including absolute ethanol $(\mathrm{EtOH})$, methanol $(\mathrm{MeOH})$ and chloroform were purchased from RCI Labscan and Merck. ${ }^{1} \mathrm{H}$ NMR spectra were measured on a Varian INOVA 400 spectrometer at $400 \mathrm{MHz}$ in $\mathrm{CDCl}_{3}$. The FTIR spectrum was obtained using a Bruker Tensor 27 spectrometer, while the mass spectrum was recorded on a Bruker microTOF-Q III. The melting point of the obtained sample was measured by a Stuart Scientific melting-point analyser (SMP10).

Fig. 8 shows the chemical structures of the starting materials and intermediate and the synthetic route of the rhodamineSchiff-base derivative studied in this work (RbSa). Firstly, the $\mathrm{RbH}$ intermediate compound was synthesized from the reaction between rhodamine $\mathrm{B}$ and hydrazine hydrate. Rhodamine B (1.20 g, $2.50 \mathrm{mmol})$ was dissolved in ethanol. An equimolar amount of hydrazine hydrate $(2.0 \mathrm{ml}, 2.5 \mathrm{mmol})$ was added to this solution. The mixture was then refluxed at $373 \mathrm{~K}$ under $\mathrm{N}_{2}$ for $2 \mathrm{~h}$. During the reaction, the colour of the solution changed from dark purple to light orange. After the reaction was complete, a precipitate of $\mathrm{RbH}$ was obtained by solvent evaporation, and then $1 \mathrm{M} \mathrm{HCl}$ was added to re-dissolve the crude product to obtain a clear red solution. After that, $1 M$ $\mathrm{NaOH}$ was added slowly in order to precipitate the purer $\mathrm{RbH}$ compound out. The obtained $\mathrm{RbH}$ was filtered under reduced pressure. The title compound $\mathrm{RbSa}$ was then prepared from the reaction of the filtered $\mathrm{RbH}(0.48 \mathrm{~g}, 0.97 \mathrm{mmol})$ and salicylaldehyde $(0.12 \mathrm{ml}, 1 \mathrm{mmol})$ in ethanolic solution. A pink precipitate of RbSa formed after reflux at $353 \mathrm{~K}$ for $12 \mathrm{~h}$ under an $\mathrm{N}_{2}$ atmosphere. The $\mathrm{RbSa}$ precipitate was separated by vacuum filtration and washed three times with cold ethanol. After recrystallization from chloroform and methanol mixed solvents with a volume ratio of $1: 1$, light-violet single crystals were obtained after several days, m.p. $495 \mathrm{~K}$.

HR-MS (ESI-TOF) $m / z:[M+1]^{+}$calculated from $\mathrm{C}_{35} \mathrm{H}_{37} \mathrm{~N}_{4} \mathrm{O}_{3}$ is 561.286017; found 561.288140.

${ }^{1} \mathrm{H}$ NMR $\left(400 \mathrm{MHz}, \mathrm{CDCl}_{3}\right.$ ) chemical shifts $(\delta): 9.31(s, 1 \mathrm{H})$, 8.10-7.90 ( $m, 1 \mathrm{H}), 7.56(s, 2 \mathrm{H}), 7.18(d q, J=7.2,4.3,3.9 \mathrm{~Hz}$, $2 \mathrm{H}), 7.13(d, J=7.8 \mathrm{~Hz}, 1 \mathrm{H}), 6.81(q, J=7.9,7.5 \mathrm{~Hz}, 3 \mathrm{H}), 6.41$ $(d, J=87.7 \mathrm{~Hz}, 5 \mathrm{H}), 3.33(s, 8 \mathrm{H}), 1.18(s, 12 \mathrm{H})$.

\section{Computational details}

All reported calculations (geometry optimizations, vibrational frequencies, and relative energies) were performed using Gaussian09 (Frisch et al., 2009) using density functional theory (DFT) at the CAM-B3LYP/6-31 G $(d)$ level. The ground-state geometries of the RbSa molecules with different conformers were optimized, and vibrational frequency calculations were performed to confirm that the optimized structures correspond well to a local minimum or a transition state. The hybrid exchange-correlation functional CAM-B3LYP was selected because it has been found to be a method of choice in important reported studies (Klinhom et al., 2019; Miengmern et al., 2019), showing a good compromise between computa-

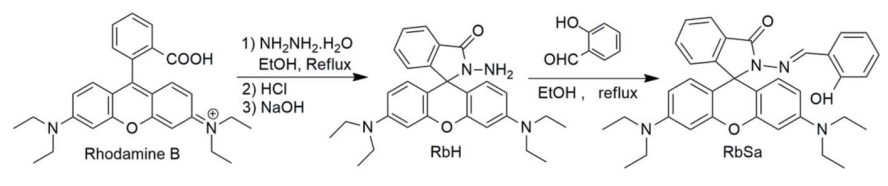

Figure 8

The synthetic route and the structures of RbSa. 
tional time and the accuracy of the results. All calculations were carried out in ethanol using a conductor-like polarizable continuum model (CPCM) (Scalmani et al., 2006).

\section{Quantum chemical calculations}

For a more in-depth insight into the molecular structures of $\mathrm{RbSa}$, density functional theory (DFT) calculations at the CAM-B3LYP/6-311 G(d,p) level were carried out. They were mainly applied to investigate the intramolecular protontransfer reaction during the enol-keto tautomerization mechanism. The molecular structures of two essential conformers (the enol and keto forms) of the title compound were first obtained by geometry optimizations without any constraints. Starting from the enol form and going to the keto form, the potential energy curve (PEC) was explored by elongating the $\mathrm{O}-\mathrm{H}$ bond in steps of $0.1 \AA$ (from 1.0 to $1.8 \AA$ ). The CAM-B3LYP optimized conformers and their relative energies are depicted in Fig. 9.

The enol form is the most stable conformer $(\mathrm{O}-\mathrm{H}=$ $0.98 \AA$ ) with the lowest relative energy, and the keto form $(\mathrm{O}-\mathrm{H}=1.76 \AA)$ is found to be slightly higher in energy than the enol form by $9.1 \mathrm{kcal} \mathrm{mol}^{-1}$. All along the tautomerization path, the six atoms involved in the initial $S(6)$ graph-set motif remain coplanar, but a rotation occurs around the $\mathrm{N}-\mathrm{N}$ bond between the diaminoxanthene and the salicylidene aniline moieties, which move from being coplanar in the enol form to being nearly perpendicular in the keto-form (Fig. 9). The rotation of the $\mathrm{N}-\mathrm{N}$ bond gives rise to the elongation and then the breakage of the $\mathrm{O}-\mathrm{H}$ bond in the enol form, resulting in the formation of the $\mathrm{N}-\mathrm{H}$ bond (keto form). Although the enol-keto tautomerization involves breakage of the $\mathrm{O}-\mathrm{H}$ bond, the intramolecular hydrogen-bonded $S(6)$

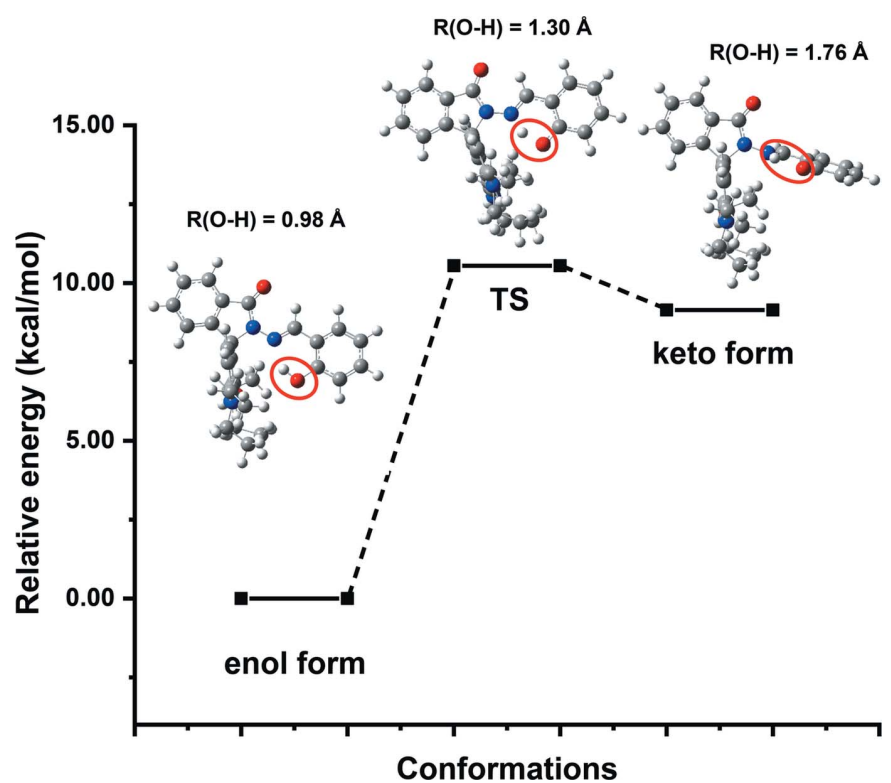

Figure 9

Optimized structures and relative energies of the enol form, the keto form and the transition state formed during the tautomerization process of the compound RbSa, calculated in ethanol at the CAM-B3LYP level using a $6-311 \mathrm{G}(\mathrm{d}, \mathrm{p})$ basis set.
Table 2

Experimental details.

\begin{tabular}{ll}
\hline Crystal data & \\
Chemical formula & $\mathrm{C}_{35} \mathrm{H}_{36} \mathrm{~N}_{4} \mathrm{O}_{3}$ \\
$M_{\mathrm{r}}$ & 560.68 \\
Crystal system, space group & Monoclinic, $P 2_{1} / c$ \\
Temperature (K) & 100 \\
$a, b, c(\AA)$ & $9.3903(7), 26.8178(19)$, \\
& $11.5639(8)$ \\
$\beta\left({ }^{\circ}\right)$ & $101.635(2)$ \\
$V\left(\AA^{3}\right)$ & $2852.3(4)$ \\
$Z$ & 4 \\
Radiation type & $\mathrm{Cu} \mathrm{K \alpha}$ \\
$\mu\left(\mathrm{mm}^{-1}\right)$ & 0.67 \\
Crystal size $(\mathrm{mm})$ & $0.20 \times 0.20 \times 0.20$
\end{tabular}

Data collection

Diffractometer

Absorption correction

$T_{\min }, T_{\max }$

No. of measured, independent and observed $[I>2 \sigma(I)]$ reflections

$R_{\text {int }}$

$(\sin \theta / \lambda)_{\max }\left(\AA^{-1}\right)$

Bruker APEXIII CCD
Multi-scan (SADABS; Bruker,
2016)
$0.673,0.754$
$64500,5508,5462$
0.030
0.618

$0.042,0.099,1.07$
5508
387
$\mathrm{H}$ atoms treated by a mixture of
independent and constrained
refinement
$0.26,-0.25$

Refinement

$R\left[F^{2}>2 \sigma\left(F^{2}\right)\right], w R\left(F^{2}\right), S$

No. of reflections

No. of parameters

$\mathrm{H}$-atom treatment

$\Delta \rho_{\max }, \Delta \rho_{\min }\left(\mathrm{e} \AA^{-3}\right)$

$0.26,-0.25$

Computer programs: APEX3 and SAINT (Bruker, 2018), SHELXT (Sheldrick, 2015a), SHELXL (Sheldrick, 2015b), OLEX2 (Dolomanov et al., 2009) and Mercury (Macrae et al., 2020).

ring still remains even in the keto form, involving the same atoms in the synthon as in the enol form. According to the relative energy calculations, it can be concluded that the phenolic $-\mathrm{OH}$ group can form a stronger intramolecular hydrogen-bonding interaction (enol form) with the $\mathrm{N}$ atom of the diaminoxanthene moiety than with the $-\mathrm{NH}$ group of the phenolate $\mathrm{O}$ in the keto closed form. The result is in a good agreement with the X-ray crystal structure in that the enol form is the dominant conformer.

Based on the highest energy structure obtained on the PEC, we optimized the molecular geometry of the transition state of the keto-enol tautomerization pathway without constraints. The single negative (imaginary) vibrational frequency calculated for the obtained structure showed that the transition state was correctly determined. The transition state lies $10.4 \mathrm{kcal} \mathrm{mol}^{-1}$ higher in energy than the enol form and only $1.3 \mathrm{kcal} \mathrm{mol}^{-1}$ above that of the keto form (Fig. 9). The optimized structure reveals an $\mathrm{O}-\mathrm{H}$ distance of $1.30 \AA$, in between the $\mathrm{O}-\mathrm{H}$ distances observed in the enol and keto conformers, but closer to that of the enol-conformer. The energy curve is rather flat between the transition state and the keto form, despite a difference of about $0.5 \AA$ between the $\mathrm{O}-\mathrm{H}$ distances (1.30 and $1.76 \AA$, respectively). Besides the fact that the enol form exhibits the lowest absolute energy and is the most stable conformer, that flatness also explains why the keto form is not as stable and can easily return to the enol form in solution under normal conditions. 


\section{Refinement}

Crystal data, data collection and structure refinement details are summarized in Table 2. The O-bound $\mathrm{H}$ atom (H3) was located in a difference-Fourier map and freely refined. The other hydrogen atoms were refined using a riding model with $d(\mathrm{C}-\mathrm{H})=0.95 \AA$ and $U_{\text {iso }}(\mathrm{H})=1.2 U_{\text {eq }}(\mathrm{C})$ for aromatic hydrogen atoms, with $d(\mathrm{C}-\mathrm{H})=0.99 \AA$ and $U_{\text {iso }}(\mathrm{H})=$ $1.2 U_{\text {eq }}(\mathrm{C})$ for $-\mathrm{CH}_{2}-$ hydrogen atoms and $d(\mathrm{C}-\mathrm{H})=0.98 \AA$, $U_{\text {iso }}(\mathrm{H})=1.5 U_{\text {eq }}(\mathrm{C})$ for the terminal methyl hydrogen atoms.

\section{Acknowledgements}

This work would not have succeeded without the funding support from the Office of the Science Research Fund (ScRF), ScAWAKE from the Faculty of Science at Bangkhen, and the Faculty of Science at Si racha campus, Kasetsart University. The Center of Nanotechnology Kasetsart University, Kasetsart University Research and Development Institute (KURDI), National Nanotechnology Center (NANOTEC), Laboratory of Computational and Applied Chemistry (LCAC), the Commission on Higher Education, Ministry of Education [through the National Research University Project of Thailand (NRU) and the National Center of Excellence for Petroleum, Petrochemical and Advanced Materials (NCEPPAM)] are gratefully acknowledged for research facilities.

\section{References}

Adhikesavalu, D. N., Mastropaolo, D., Camerman, A. \& Camerman, N. (2001). Acta Cryst. C57, 657-659.

Bao, X., Liu, D., Jin, Y., Liu, X. \& Jiang, W. (2013). RSC Adv. 3, $6783-$ 6786.

Biswal, B. \& Bag, B. (2013). Org. Biomol. Chem. 11, 4975-4992.

Bruker (2016). SADABS. Bruker AXS Inc., Madison, Wisconsin, USA.

Bruker (2018). APEX3 and SAINT. Bruker AXS Inc., Madison, Wisconsin, USA.

Dolomanov, O. V., Bourhis, L. J., Gildea, R. J., Howard, J. A. K. \& Puschmann, H. (2009). J. Appl. Cryst. 42, 339-341.

Frisch, M. J., Trucks, G. W., Schlegel, H. B., Scuseria, G. E., Robb, M. A., Cheeseman, J. R., Scalmani, G., Barone, V., Mennucci, B., Petersson, G. A., Nakatsuji, H., Caricato, M., Li, X., Hratchian, H. P., Izmaylov, A. F., Bloino, J., Zheng, G., Sonnenberg, J. L., Hada, M., Ehara, M., Toyota, K., Fukuda, R., Hasegawa, J., Ishida, M., Nakajima, T., Honda, Y., Kitao, O., Nakai, H., Vreven, T., Montgomery, J. A. Jr, Peralta, J. E., Ogliaro, F., Bearpark, M., Heyd, J. J., Brothers, E., Kudin, K. N., Staroverov, V. N., Kobayashi,
R., Normand, J., Raghavachari, K., Rendell, A., Burant, J. C., Iyengar, S. S., Tomasi, J., Cossi, M., Rega, N., Millam, J. M., Klene, M., Knox, J. E., Cross, J. B., Bakken, V., Adamo, C., Jaramillo, J., Gomperts, R., Stratmann, R. E., Yazyev, O., Austin, A. J., Cammi, R., Pomelli, C., Ochterski, J. W., Martin, R. L., Morokuma, K., Zakrzewski, V. G., Voth, G. A., Salvador, P., Dannenberg, J. J., Dapprich, S., Daniels, A. D., Farkas, Ö., Foresman, J. B., Ortiz, J. V., Cioslowski, J. \& Fox, D. J. (2009). GAUSSIAN09. Gaussian Inc., Wallingford, Connecticut, USA.

Fun, H.-K., Chinnakali, K., Sivakumar, K., Lu, C.-M., Xiong, R.-G. \& You, X.-Z. (1997). Acta Cryst. C53, 1619-1620.

Groom, C. R., Bruno, I. J., Lightfoot, M. P. \& Ward, S. C. (2016). Acta Cryst. B72, 171-179.

Hirshfeld, F. L. (1977). Theor. Chim. Acta, 44, 129-138.

Kim, H. N., Lee, M. H., Kim, H. J., Kim, J. S. \& Yoon, J. (2008). Chem. Soc. Rev. 37, 1465-1472.

Klinhom, N., Saengsuwan, N., Sriyab, S., Prompinit, P., Hannongbua, S. \& Suramitr, S. (2019). Spectrochim. Acta Part A, 206, 359-366.

Kvick, A., Vaughan, G. B. M., Wang, X., Sun, Y. \& Long, Y. (2000). Acta Cryst. C56, 1232-1233.

Kwon, J. Y., Jang, Y. J., Lee, Y. J., Kim, K. M., Seo, M. S., Nam, W. \& Yoon, J. (2005). J. Am. Chem. Soc. 127, 10107-10111.

Liu, J., Wu, D., Yan, X. \& Guan, Y. (2013). Talanta, 116, 563-568.

Macrae, C. F., Sovago, I., Cottrell, S. J., Galek, P. T. A., McCabe, P., Pidcock, E., Platings, M., Shields, G. P., Stevens, J. S., Towler, M. \& Wood, P. A. (2020). J. Appl. Cryst. 53, 226-235.

McKinnon, J. J., Jayatilaka, D. \& Spackman, M. A. (2007). Chem. Commun. pp. 3814-3816.

Miengmern, N., Koonwong, A., Sriyab, S., Suramitr, A., Poo-arporn, R. P., Hannongbua, S. \& Suramitr, S. (2019). J. Lumin. 210, 493500.

Mizuguchi, J. (2008). Acta Cryst. E64, o1238-o1239.

Ni, J., Li, Q., Li, B. \& Zhang, L. (2013). Sens. Actuators B Chem. 186, 278-285.

Qu, J. Q., Wang, L. F., Li, Y. Z., Sun, G. C., Zhu, Q. J. \& Xia, C. G. (2001). Synth. React. Inorg. Met.-Org. Chem. 31, 1577-1585.

Quang, D. T. \& Kim, J. S. (2010). Chem. Rev. 110, 6280-6301.

Scalmani, G., Frisch, M. J., Mennucci, B., Tomasi, J., Cammi, R. \& Barone, V. (2006). J. Chem. Phys. 124, 094107.

Sheldrick, G. M. (2015a). Acta Cryst. A71, 3-8.

Sheldrick, G. M. (2015b). Acta Cryst. C71, 3-8.

Spackman, M. A. \& Jayatilaka, D. (2009). CrystEngComm, 11, 19-32.

Turner, M. J., McKinnon, J. J., Wolff, S. K., Grimwood, D. J., Spackman, P. R., Jayatilaka, D. \& Spackman, M. A. (2017). Crystal Explorer 17.5. The University of Western Australia.

Venkatraman, R., Sitole, L. \& Fronczek, F. R. (2008). Acta Cryst. E64, m199.

Veranitisagul, C., Wattanathana, W., Kaewvilai, A., Duangthongyou, T., Laobuthee, A. \& Koonsaeng, N. (2012). Acta Cryst. E68, o1826.

Wattanathana, W., Nootsuwan, N., Veranitisagul, C., Koonsaeng, N., Suramitr, S. \& Laobuthee, A. (2016). J. Mol. Struct. 1109, 201-208.

Wattanathana, W., Veranitisagul, C., Kaewvilai, A., Laobuthee, A. \& Koonsaeng, N. (2012). Acta Cryst. E68, o3050. 


\section{supporting information}

Acta Cryst. (2020). E76, 1027-1032 [https://doi.org/10.1107/S2056989020007197]

\section{Crystal structure, Hirshfeld surface analysis and computational study of a} rhodamine B-salicylaldehyde Schiff base derivative

Songwut Suramitr, Jitpinan Teanwarawat, Nuttapong Ithiapa, Worawat Wattanathana and Anwaraporn Suramitr

Computing details

Data collection: APEX3 (Bruker, 2018); cell refinement: SAINT (Bruker, 2018); data reduction: SAINT (Bruker, 2018); program(s) used to solve structure: SHELXT (Sheldrick, 2015a); program(s) used to refine structure: SHELXL

(Sheldrick, 2015b); molecular graphics: OLEX2 (Dolomanov et al., 2009), Mercury (Macrae et al., 2020); software used to prepare material for publication: OLEX2 (Dolomanov et al., 2009).

3',6'-Bis(diethylamino)-2-[(2-hydroxybenzylidene)amino]spiro[isoindoline-1,9''-xanthen]-3-one

Crystal data

$\mathrm{C}_{35} \mathrm{H}_{36} \mathrm{~N}_{4} \mathrm{O}_{3}$

$M_{r}=560.68$

Monoclinic, $P 2_{1} / c$

$a=9.3903(7) \AA$

$b=26.8178(19) \AA$

$c=11.5639(8) \AA$

$\beta=101.635(2)^{\circ}$

$V=2852.3(4) \AA^{3}$

$Z=4$

\section{Data collection}

Bruker APEXIII CCD

diffractometer

$\varphi$ and $\omega$ scans

Absorption correction: multi-scan

(SADABS; Bruker, 2016)

$T_{\text {min }}=0.673, T_{\max }=0.754$

64500 measured reflections

\section{Refinement}

Refinement on $F^{2}$

Least-squares matrix: full

$R\left[F^{2}>2 \sigma\left(F^{2}\right)\right]=0.042$

$w R\left(F^{2}\right)=0.099$

$S=1.07$

5508 reflections

387 parameters

0 restraints

Primary atom site location: dual
$F(000)=1192$

$D_{\mathrm{x}}=1.306 \mathrm{Mg} \mathrm{m}^{-3}$

$\mathrm{Cu} K \alpha$ radiation, $\lambda=1.54178 \AA$

Cell parameters from 9681 reflections

$\theta=3.9-72.1^{\circ}$

$\mu=0.67 \mathrm{~mm}^{-1}$

$T=100 \mathrm{~K}$

Block, clear light violet

$0.20 \times 0.20 \times 0.20 \mathrm{~mm}$

5508 independent reflections

5462 reflections with $I>2 \sigma(I)$

$R_{\text {int }}=0.030$

$\theta_{\text {max }}=72.2^{\circ}, \theta_{\text {min }}=5.1^{\circ}$

$h=-11 \rightarrow 11$

$k=-33 \rightarrow 31$

$l=-14 \rightarrow 14$

Hydrogen site location: mixed

$\mathrm{H}$ atoms treated by a mixture of independent and constrained refinement

$w=1 /\left[\sigma^{2}\left(F_{\mathrm{o}}^{2}\right)+(0.0366 P)^{2}+1.6105 P\right]$ where $P=\left(F_{\mathrm{o}}^{2}+2 F_{\mathrm{c}}^{2}\right) / 3$

$(\Delta / \sigma)_{\max }=0.001$

$\Delta \rho_{\max }=0.26 \mathrm{e} \AA^{-3}$

$\Delta \rho_{\min }=-0.25$ e $\AA^{-3}$ 


\section{Special details}

Geometry. All esds (except the esd in the dihedral angle between two 1.s. planes) are estimated using the full covariance matrix. The cell esds are taken into account individually in the estimation of esds in distances, angles and torsion angles; correlations between esds in cell parameters are only used when they are defined by crystal symmetry. An approximate (isotropic) treatment of cell esds is used for estimating esds involving l.s. planes.

Fractional atomic coordinates and isotropic or equivalent isotropic displacement parameters $\left(\hat{A}^{2}\right)$

\begin{tabular}{|c|c|c|c|c|}
\hline & $x$ & $y$ & $z$ & $U_{\text {iso }} * / U_{\text {eq }}$ \\
\hline $\mathrm{O} 1$ & $0.63421(9)$ & $0.53998(3)$ & $0.51482(7)$ & 0.01990 (19) \\
\hline $\mathrm{O} 2$ & $0.35333(10)$ & 0.71057 (3) & $0.15605(8)$ & $0.0258(2)$ \\
\hline $\mathrm{O} 3$ & $0.85258(11)$ & $0.67163(4)$ & $0.47128(9)$ & $0.0341(2)$ \\
\hline N3 & $0.47258(11)$ & $0.64737(4)$ & $0.27590(9)$ & $0.0182(2)$ \\
\hline $\mathrm{N} 2$ & $0.78424(11)$ & $0.43998(4)$ & $0.22361(9)$ & $0.0203(2)$ \\
\hline N4 & $0.61281(11)$ & $0.66475(4)$ & $0.30950(9)$ & $0.0197(2)$ \\
\hline N1 & $0.54337(12)$ & $0.63079(4)$ & $0.84325(9)$ & $0.0228(2)$ \\
\hline $\mathrm{C} 27$ & $0.22734(13)$ & $0.63956(4)$ & $0.22148(10)$ & $0.0181(2)$ \\
\hline $\mathrm{C} 12$ & $0.52489(12)$ & $0.55798(4)$ & $0.31027(10)$ & $0.0163(2)$ \\
\hline $\mathrm{C} 9$ & $0.56210(12)$ & $0.58015(4)$ & $0.55053(10)$ & $0.0167(2)$ \\
\hline $\mathrm{C} 22$ & $0.27539(12)$ & $0.59856(4)$ & $0.29156(10)$ & 0.0165 (2) \\
\hline $\mathrm{C} 8$ & $0.46927(12)$ & $0.61076(4)$ & $0.47253(10)$ & 0.0165 (2) \\
\hline $\mathrm{C} 13$ & $0.61868(12)$ & $0.53104(4)$ & $0.39588(10)$ & $0.0163(2)$ \\
\hline $\mathrm{C} 17$ & $0.70486(13)$ & $0.49250(4)$ & $0.36853(10)$ & $0.0174(2)$ \\
\hline H17 & 0.767903 & 0.475358 & 0.430372 & $0.021^{*}$ \\
\hline $\mathrm{C} 28$ & $0.35267(13)$ & $0.67139(4)$ & $0.21032(10)$ & 0.0185 (2) \\
\hline $\mathrm{C} 16$ & $0.70031(12)$ & $0.47851(4)$ & $0.25124(10)$ & $0.0173(2)$ \\
\hline $\mathrm{C} 10$ & $0.58838(13)$ & $0.58696(5)$ & $0.67180(10)$ & $0.0188(2)$ \\
\hline H10 & 0.652938 & 0.565077 & 0.721574 & $0.023^{*}$ \\
\hline C11 & $0.43818(12)$ & $0.60188(4)$ & $0.34033(10)$ & 0.0165 (2) \\
\hline $\mathrm{C} 7$ & $0.40438(13)$ & $0.64983(5)$ & $0.52325(11)$ & 0.0199 (3) \\
\hline $\mathrm{H} 7$ & 0.340634 & 0.671699 & 0.472730 & $0.024^{*}$ \\
\hline $\mathrm{C} 5$ & $0.52106(13)$ & $0.62564(5)$ & $0.72189(11)$ & $0.0190(2)$ \\
\hline C6 & $0.42897(13)$ & $0.65798(5)$ & 0.64345 (11) & $0.0212(3)$ \\
\hline H6 & 0.383917 & 0.685408 & 0.673746 & $0.025^{*}$ \\
\hline $\mathrm{C} 24$ & $0.03086(13)$ & $0.57033(5)$ & 0.26884 (11) & 0.0219 (3) \\
\hline $\mathrm{H} 24$ & -0.038019 & 0.546594 & 0.284338 & $0.026^{*}$ \\
\hline $\mathrm{C} 23$ & $0.17839(13)$ & $0.56257(5)$ & $0.31441(10)$ & $0.0190(2)$ \\
\hline $\mathrm{H} 23$ & 0.211332 & 0.533686 & 0.359496 & $0.023^{*}$ \\
\hline C15 & 0.60465 (13) & $0.50567(5)$ & $0.16302(11)$ & $0.0207(3)$ \\
\hline H15 & 0.598389 & 0.497589 & 0.082170 & $0.025^{*}$ \\
\hline $\mathrm{C} 26$ & $0.08054(14)$ & $0.64726(5)$ & $0.17477(11)$ & $0.0219(3)$ \\
\hline $\mathrm{H} 26$ & 0.048406 & 0.675417 & 0.126699 & $0.026^{*}$ \\
\hline $\mathrm{C} 14$ & $0.52070(13)$ & $0.54367(5)$ & $0.19346(11)$ & $0.0203(3)$ \\
\hline H14 & 0.457022 & 0.560945 & 0.132251 & $0.024 *$ \\
\hline $\mathrm{C} 25$ & $-0.01736(13)$ & $0.61228(5)$ & $0.20097(11)$ & $0.0231(3)$ \\
\hline $\mathrm{H} 25$ & -0.118581 & 0.617015 & 0.172246 & $0.028^{*}$ \\
\hline $\mathrm{C} 29$ & $0.66197(14)$ & $0.69802(5)$ & $0.24752(11)$ & $0.0226(3)$ \\
\hline $\mathrm{H} 29$ & 0.603743 & 0.709238 & 0.175314 & $0.027^{*}$ \\
\hline
\end{tabular}




$\begin{array}{lllll}\text { C21 } & 0.88015(14) & 0.41198(5) & 0.31614(11) & 0.0228(3) \\ \text { H21A } & 0.901201 & 0.379277 & 0.283556 & 0.027^{*} \\ \text { H21B } & 0.827910 & 0.405544 & 0.380933 & 0.027^{*} \\ \text { C30 } & 0.80710(15) & 0.71842(5) & 0.28840(12) & 0.0249(3) \\ \text { C4 } & 0.67041(14) & 0.60808(5) & 0.91783(11) & 0.0250(3) \\ \text { H4A } & 0.670275 & 0.571911 & 0.900719 & 0.030^{*} \\ \text { H4B } & 0.663083 & 0.612091 & 1.001535 & 0.030^{*} \\ \text { C19 } & 0.78644(15) & 0.42836(5) & 0.10088(11) & 0.0230(3) \\ \text { H19A } & 0.685046 & 0.427015 & 0.055715 & 0.028^{*} \\ \text { H19B } & 0.829533 & 0.394843 & 0.097343 & 0.028^{*} \\ \text { C2 } & 0.46026(14) & 0.66609(5) & 0.89867(11) & 0.0236(3) \\ \text { H2A } & 0.454398 & 0.653305 & 0.977887 & 0.028^{*} \\ \text { H2B } & 0.359964 & 0.667543 & 0.851350 & 0.028^{*} \\ \text { C35 } & 0.89543(15) & 0.70507(5) & 0.39724(13) & 0.0284(3) \\ \text { C3 } & 0.81405(15) & 0.63038(6) & 0.90053(12) & 0.0310(3) \\ \text { H3A } & 0.820426 & 0.627884 & 0.817176 & 0.046^{*} \\ \text { H3B } & 0.894997 & 0.612070 & 0.948926 & 0.046^{*} \\ \text { H3C } & 0.819047 & 0.665505 & 0.924369 & 0.046^{*} \\ \text { C18 } & 0.87120(16) & 0.46553(5) & 0.04151(12) & 0.0287(3) \\ \text { H18A } & 0.866719 & 0.455502 & -0.040637 & 0.043^{*} \\ \text { H18B } & 0.972824 & 0.466195 & 0.083581 & 0.043^{*} \\ \text { H18C } & 0.828601 & 0.498805 & 0.043386 & 0.043^{*} \\ \text { C20 } & 1.02371(15) & 0.43748(5) & 0.36756(13) & 0.0291(3) \\ \text { H20A } & 1.077556 & 0.443530 & 0.304608 & 0.044^{*} \\ \text { H20B } & 1.081375 & 0.416020 & 0.428003 & 0.044^{*} \\ \text { H20C } & 1.004643 & 0.469316 & 0.403179 & 0.044^{*} \\ \text { C1 } & 0.52129(17) & 0.71867(5) & 0.91209(13) & 0.0319(3) \\ \text { H1A } & 0.517760 & 0.733206 & 0.833812 & 0.048^{*} \\ \text { H1B } & 0.622293 & 0.717668 & 0.955531 & 0.048^{*} \\ \text { H1C } & 0.463219 & 0.739067 & 0.955591 & 0.048^{*} \\ \text { C31 } & 0.85986(17) & 0.75357(5) & 0.21765(14) & 0.0332(3) \\ \text { H31 } & 0.800983 & 0.763165 & 0.144281 & 0.040^{*} \\ \text { C32 } & 0.99603(19) & 0.77443(6) & 0.25302(17) & 0.0412(4) \\ \text { H32 } & 1.031113 & 0.797800 & 0.203696 & 0.049^{*} \\ \text { C34 } & 1.03266(16) & 0.72693(6) & 0.43299(16) & 0.0377(4) \\ \text { H34 } & 1.092100 & 0.718219 & 0.506806 & 0.045^{*} \\ \text { C33 } & 1.08133(17) & 0.76114(6) & 0.36078(17) & 0.0430(4) \\ \text { H33 } & 1.174654 & 0.775796 & 0.385279 & 0.052^{*} \\ \text { H3 } & 0.752(3) & 0.6591(9) & 0.431(2) & 0.069(7)^{*} \\ & & & & \end{array}$

Atomic displacement parameters $\left(\AA^{2}\right)$

\begin{tabular}{lllllll}
\hline & $U^{11}$ & $U^{22}$ & $U^{33}$ & $U^{12}$ & $U^{13}$ & $U^{23}$ \\
\hline O1 & $0.0224(4)$ & $0.0236(4)$ & $0.0129(4)$ & $0.0070(3)$ & $0.0017(3)$ & $-0.0005(3)$ \\
O2 & $0.0281(5)$ & $0.0213(5)$ & $0.0272(5)$ & $0.0023(4)$ & $0.0035(4)$ & $0.0077(4)$ \\
O3 & $0.0246(5)$ & $0.0390(6)$ & $0.0363(6)$ & $-0.0069(4)$ & $0.0001(4)$ & $0.0078(4)$ \\
N3 & $0.0162(5)$ & $0.0190(5)$ & $0.0188(5)$ & $-0.0012(4)$ & $0.0022(4)$ & $0.0035(4)$ \\
N2 & $0.0205(5)$ & $0.0219(5)$ & $0.0190(5)$ & $0.0026(4)$ & $0.0049(4)$ & $-0.0014(4)$
\end{tabular}




\begin{tabular}{|c|c|c|c|c|c|c|}
\hline N4 & $0.0169(5)$ & $0.0197(5)$ & 0.0233 & $-0.0016(4)$ & $0.0062(4)$ & -0.0019 \\
\hline N1 & $0.0207(5)$ & $0.0305(6)$ & $0.0171(5)$ & $0.0025(4)$ & $0.0034(4)$ & $-0.0042(4)$ \\
\hline $\mathrm{C} 27$ & $0.0193(6)$ & $0.0197(6)$ & $0.0148(5)$ & $0.0016(5)$ & $0.0025(4)$ & $-0.0018(4)$ \\
\hline C12 & $0.0140(5)$ & $0.0188(6)$ & $0.0162(5)$ & $-0.0012(4)$ & 0.0028 & $0.0014(4)$ \\
\hline $\mathrm{C} 9$ & $0.0137(5)$ & $0.0185(6)$ & $0.0180(6)$ & $-0.0007(4)$ & $0.0036(4)$ & -0.0005 (4) \\
\hline $\mathrm{C} 22$ & $0.0154(6)$ & $0.0204(6)$ & $0.0134(5)$ & $0.0012(4)$ & $0.0023(4)$ & $-0.0022(4)$ \\
\hline $\mathrm{C} 8$ & $0.0134(5)$ & $0.0195(6)$ & $0.0164(6)$ & $-0.0024(4)$ & $0.0024(4)$ & $0.0003(4)$ \\
\hline C13 & $0.0154(5)$ & $0.0200(6)$ & $0.0134(5)$ & $-0.0023(4)$ & $0.0030(4)$ & $0.0003(4)$ \\
\hline $\mathrm{C} 17$ & $0.0155(5)$ & $0.0206(6)$ & $0.0157(5)$ & $0.0006(4)$ & $0.0020(4)$ & $0.0026(4)$ \\
\hline $\mathrm{C} 28$ & $0.0211(6)$ & $0.0188(6)$ & 0.0155 & $0.0021(5)$ & $0.0031(4)$ & -0.0002 \\
\hline $\mathrm{C} 16$ & $0.0152(5)$ & $0.0185(6)$ & $0.0190(6)$ & $-0.0023(4)$ & $0.0053(4)$ & -0.0004 \\
\hline $\mathrm{C} 10$ & $0.0162(5)$ & $0.0230(6)$ & $0.0164(6)$ & $0.0005(5)$ & $0.0014(4)$ & $0.0006(5)$ \\
\hline $\mathrm{C} 11$ & $0.0151(5)$ & $0.0177(6)$ & $0.0163(6)$ & $-0.0009(4)$ & $0.0022(4)$ & $0.0028(4)$ \\
\hline $\mathrm{C} 7$ & $0.0173(6)$ & $0.0210(6)$ & $0.0206(6)$ & $0.0011(5)$ & $0.0017(5)$ & $0.0008(5)$ \\
\hline $\mathrm{C} 5$ & $0.0152(5)$ & $0.0238(6)$ & $0.0178(6)$ & $-0.0035(5)$ & $0.0030(4)$ & $-0.0027(5)$ \\
\hline C6 & $0.0187(6)$ & $0.0220(6)$ & $0.0230(6)$ & $0.0005(5)$ & $0.0049(5)$ & $-0.0042(5)$ \\
\hline $\mathrm{C} 24$ & $0.0182(6)$ & $0.0286(7)$ & $0.0190(6)$ & $-0.0046(5)$ & $0.0043(5)$ & -0.0040 \\
\hline $\mathrm{C} 23$ & $0.0190(6)$ & $0.0223(6)$ & 0.0155 & -0.0009 (5) & $0.0031(4)$ & $0.0000(4)$ \\
\hline $\mathrm{C} 15$ & $0.0204(6)$ & $0.0270(6)$ & $0.0146(6)$ & $0.0005(5)$ & $0.0030(5)$ & $-0.0011(5)$ \\
\hline $\mathrm{C} 26$ & $0.0207(6)$ & $0.0237(6)$ & $0.0193(6)$ & $0.0055(5)$ & $-0.0010(5)$ & -0.0020 \\
\hline C14 & $0.0184(6)$ & $0.0260(6)$ & $0.0152(6)$ & $0.0022(5)$ & $0.0004(4)$ & $0.0030(5)$ \\
\hline $\mathrm{C} 25$ & $0.0154(6)$ & $0.0310(7)$ & $0.0211(6)$ & $0.0033(5)$ & $-0.0005(5)$ & $-0.0059(5)$ \\
\hline $\mathrm{C} 29$ & $0.0251(6)$ & $0.0210(6)$ & $0.0233(6)$ & $0.0005(5)$ & $0.0089(5)$ & $0.0002(5)$ \\
\hline $\mathrm{C} 21$ & $0.0251(6)$ & $0.0182(6)$ & $0.0251(6)$ & $0.0039(5)$ & $0.0051(5)$ & $0.0008(5)$ \\
\hline $\mathrm{C} 30$ & $0.0247(6)$ & $0.0198(6)$ & $0.0337(7)$ & $-0.0014(5)$ & $0.0140(5)$ & $-0.0049(5)$ \\
\hline $\mathrm{C} 4$ & $0.0279(7)$ & $0.0312(7)$ & $0.0150(6)$ & $0.0024(5)$ & $0.0024(5)$ & $-0.0011(5)$ \\
\hline C19 & $0.0266(6)$ & $0.0218(6)$ & $0.0216(6)$ & $0.0006(5)$ & $0.0070(5)$ & $-0.0046(5)$ \\
\hline $\mathrm{C} 2$ & $0.0243(6)$ & $0.0268(7)$ & $0.0209(6)$ & $-0.0003(5)$ & $0.0077(5)$ & $-0.0025(5)$ \\
\hline $\mathrm{C} 35$ & $0.0245(7)$ & $0.0244(7)$ & $0.0389(8)$ & $-0.0034(5)$ & $0.0127(6)$ & $-0.0033(6)$ \\
\hline C3 & $0.0224(7)$ & $0.0430(8)$ & $0.0256(7)$ & $0.0025(6)$ & $0.0001(5)$ & $-0.0057(6)$ \\
\hline $\mathrm{C} 18$ & $0.0343(7)$ & $0.0289(7)$ & $0.0266(7)$ & $0.0014(6)$ & $0.0148(6)$ & $-0.0016(5)$ \\
\hline $\mathrm{C} 20$ & $0.0221(7)$ & $0.0307(7)$ & $0.0331(7)$ & $0.0046(5)$ & 0.0025 & $0.0019(6)$ \\
\hline $\mathrm{C} 1$ & $0.0384(8)$ & $0.0276(7)$ & $0.0301(7)$ & $-0.0034(6)$ & $0.0077(6)$ & $-0.0012(6)$ \\
\hline C31 & $0.0397(8)$ & $0.0232(7)$ & $0.0420(8)$ & $-0.0045(6)$ & $0.0206(7)$ & $-0.0024(6)$ \\
\hline $\mathrm{C} 32$ & $0.0438(9)$ & $0.0266(7)$ & $0.0615(11)$ & $-0.0123(7)$ & $0.0304(8)$ & $-0.0067(7)$ \\
\hline $\mathrm{C} 34$ & $0.0244(7)$ & $0.0379(8)$ & $0.0513(9)$ & $-0.0051(6)$ & $0.0086(6)$ & $-0.0074(7)$ \\
\hline C33 & $0.0283(8)$ & $0.0346(8)$ & $0.0708(12)$ & $-0.0142(6)$ & $0.0214(8)$ & $-0.0154(8)$ \\
\hline
\end{tabular}

Geometric parameters $\left(\AA,{ }^{\circ}\right)$

\begin{tabular}{llll}
\hline $\mathrm{O} 1-\mathrm{C} 9$ & $1.3792(14)$ & $\mathrm{C} 15-\mathrm{C} 14$ & $1.3768(18)$ \\
$\mathrm{O} 1-\mathrm{C} 13$ & $1.3747(14)$ & $\mathrm{C} 26-\mathrm{H} 26$ & 0.9500 \\
$\mathrm{O} 2-\mathrm{C} 28$ & $1.2246(15)$ & $\mathrm{C} 26-\mathrm{C} 25$ & $1.3890(19)$ \\
$\mathrm{O} 3-\mathrm{C} 35$ & $1.3558(17)$ & $\mathrm{C} 14-\mathrm{H} 14$ & 0.9500 \\
$\mathrm{O} 3-\mathrm{H} 3$ & $1.02(3)$ & $\mathrm{C} 25-\mathrm{H} 25$ & 0.9500 \\
$\mathrm{~N} 3-\mathrm{N} 4$ & $1.3769(14)$ & $\mathrm{C} 29-\mathrm{H} 29$ & 0.9500 \\
$\mathrm{~N} 3-\mathrm{C} 28$ & $1.3833(15)$ & $\mathrm{C} 29-\mathrm{C} 30$ & $1.4561(19)$ \\
$\mathrm{N} 3-\mathrm{C} 11$ & $1.4982(14)$ & $\mathrm{C} 21-\mathrm{H} 21 \mathrm{~A}$ & 0.9900
\end{tabular}




\begin{tabular}{|c|c|c|c|}
\hline $\mathrm{N} 2-\mathrm{C} 16$ & $1.3758(16)$ & $\mathrm{C} 21-\mathrm{H} 21 \mathrm{~B}$ & 0.9900 \\
\hline $\mathrm{N} 2-\mathrm{C} 21$ & $1.4599(16)$ & $\mathrm{C} 21-\mathrm{C} 20$ & $1.5216(19)$ \\
\hline $\mathrm{N} 2-\mathrm{C} 19$ & $1.4572(16)$ & $\mathrm{C} 30-\mathrm{C} 35$ & $1.407(2)$ \\
\hline $\mathrm{N} 4-\mathrm{C} 29$ & $1.2870(17)$ & $\mathrm{C} 30-\mathrm{C} 31$ & 1.4025 (19) \\
\hline $\mathrm{N} 1-\mathrm{C} 5$ & $1.3834(16)$ & $\mathrm{C} 4-\mathrm{H} 4 \mathrm{~A}$ & 0.9900 \\
\hline $\mathrm{N} 1-\mathrm{C} 4$ & $1.4569(17)$ & $\mathrm{C} 4-\mathrm{H} 4 \mathrm{~B}$ & 0.9900 \\
\hline $\mathrm{N} 1-\mathrm{C} 2$ & $1.4551(16)$ & $\mathrm{C} 4-\mathrm{C} 3$ & $1.525(2)$ \\
\hline $\mathrm{C} 27-\mathrm{C} 22$ & $1.3864(17)$ & C19-H19A & 0.9900 \\
\hline $\mathrm{C} 27-\mathrm{C} 28$ & $1.4803(17)$ & C19-H19B & 0.9900 \\
\hline $\mathrm{C} 27-\mathrm{C} 26$ & 1.3907 (17) & $\mathrm{C} 19-\mathrm{C} 18$ & $1.5227(18)$ \\
\hline $\mathrm{C} 12-\mathrm{C} 13$ & $1.3879(16)$ & $\mathrm{C} 2-\mathrm{H} 2 \mathrm{~A}$ & 0.9900 \\
\hline $\mathrm{C} 12-\mathrm{C} 11$ & $1.5113(16)$ & $\mathrm{C} 2-\mathrm{H} 2 \mathrm{~B}$ & 0.9900 \\
\hline $\mathrm{C} 12-\mathrm{C} 14$ & $1.3970(17)$ & $\mathrm{C} 2-\mathrm{C} 1$ & $1.5183(19)$ \\
\hline $\mathrm{C} 9-\mathrm{C} 8$ & $1.3892(17)$ & $\mathrm{C} 35-\mathrm{C} 34$ & $1.400(2)$ \\
\hline $\mathrm{C} 9-\mathrm{C} 10$ & $1.3861(17)$ & $\mathrm{C} 3-\mathrm{H} 3 \mathrm{~A}$ & 0.9800 \\
\hline $\mathrm{C} 22-\mathrm{C} 11$ & $1.5215(16)$ & $\mathrm{C} 3-\mathrm{H} 3 \mathrm{~B}$ & 0.9800 \\
\hline $\mathrm{C} 22-\mathrm{C} 23$ & $1.3885(17)$ & $\mathrm{C} 3-\mathrm{H} 3 \mathrm{C}$ & 0.9800 \\
\hline $\mathrm{C} 8-\mathrm{C} 11$ & $1.5163(16)$ & $\mathrm{C} 18-\mathrm{H} 18 \mathrm{~A}$ & 0.9800 \\
\hline $\mathrm{C} 8-\mathrm{C} 7$ & $1.3990(17)$ & $\mathrm{C} 18-\mathrm{H} 18 \mathrm{~B}$ & 0.9800 \\
\hline $\mathrm{C} 13-\mathrm{C} 17$ & $1.3878(17)$ & $\mathrm{C} 18-\mathrm{H} 18 \mathrm{C}$ & 0.9800 \\
\hline C17- $\mathrm{H} 17$ & 0.9500 & $\mathrm{C} 20-\mathrm{H} 20 \mathrm{~A}$ & 0.9800 \\
\hline $\mathrm{C} 17-\mathrm{C} 16$ & $1.3997(17)$ & $\mathrm{C} 20-\mathrm{H} 20 \mathrm{~B}$ & 0.9800 \\
\hline $\mathrm{C} 16-\mathrm{C} 15$ & $1.4172(17)$ & $\mathrm{C} 20-\mathrm{H} 20 \mathrm{C}$ & 0.9800 \\
\hline $\mathrm{C} 10-\mathrm{H} 10$ & 0.9500 & $\mathrm{C} 1-\mathrm{H} 1 \mathrm{~A}$ & 0.9800 \\
\hline $\mathrm{C} 10-\mathrm{C} 5$ & $1.3996(17)$ & $\mathrm{C} 1-\mathrm{H} 1 \mathrm{~B}$ & 0.9800 \\
\hline $\mathrm{C} 7-\mathrm{H} 7$ & 0.9500 & $\mathrm{C} 1-\mathrm{H} 1 \mathrm{C}$ & 0.9800 \\
\hline $\mathrm{C} 7-\mathrm{C} 6$ & $1.3798(18)$ & C31-H31 & 0.9500 \\
\hline $\mathrm{C} 5-\mathrm{C} 6$ & $1.4165(18)$ & $\mathrm{C} 31-\mathrm{C} 32$ & $1.380(2)$ \\
\hline C6-H6 & 0.9500 & $\mathrm{C} 32-\mathrm{H} 32$ & 0.9500 \\
\hline $\mathrm{C} 24-\mathrm{H} 24$ & 0.9500 & $\mathrm{C} 32-\mathrm{C} 33$ & $1.385(3)$ \\
\hline $\mathrm{C} 24-\mathrm{C} 23$ & $1.3949(17)$ & $\mathrm{C} 34-\mathrm{H} 34$ & 0.9500 \\
\hline $\mathrm{C} 24-\mathrm{C} 25$ & $1.3941(19)$ & $\mathrm{C} 34-\mathrm{C} 33$ & $1.379(2)$ \\
\hline $\mathrm{C} 23-\mathrm{H} 23$ & 0.9500 & $\mathrm{C} 33-\mathrm{H} 33$ & 0.9500 \\
\hline C15-H15 & 0.9500 & & \\
\hline $\mathrm{C} 13-\mathrm{O} 1-\mathrm{C} 9$ & $118.45(9)$ & $\mathrm{C} 24-\mathrm{C} 25-\mathrm{H} 25$ & 119.5 \\
\hline $\mathrm{C} 35-\mathrm{O} 3-\mathrm{H} 3$ & $107.4(13)$ & $\mathrm{C} 26-\mathrm{C} 25-\mathrm{C} 24$ & $120.91(11)$ \\
\hline $\mathrm{N} 4-\mathrm{N} 3-\mathrm{C} 28$ & $128.56(10)$ & $\mathrm{C} 26-\mathrm{C} 25-\mathrm{H} 25$ & 119.5 \\
\hline $\mathrm{N} 4-\mathrm{N} 3-\mathrm{C} 11$ & $115.17(9)$ & $\mathrm{N} 4-\mathrm{C} 29-\mathrm{H} 29$ & 120.1 \\
\hline $\mathrm{C} 28-\mathrm{N} 3-\mathrm{C} 11$ & $114.74(9)$ & $\mathrm{N} 4-\mathrm{C} 29-\mathrm{C} 30$ & $119.81(12)$ \\
\hline $\mathrm{C} 16-\mathrm{N} 2-\mathrm{C} 21$ & $120.92(10)$ & $\mathrm{C} 30-\mathrm{C} 29-\mathrm{H} 29$ & 120.1 \\
\hline $\mathrm{C} 16-\mathrm{N} 2-\mathrm{C} 19$ & $120.53(10)$ & $\mathrm{N} 2-\mathrm{C} 21-\mathrm{H} 21 \mathrm{~A}$ & 108.5 \\
\hline $\mathrm{C} 19-\mathrm{N} 2-\mathrm{C} 21$ & $118.42(10)$ & $\mathrm{N} 2-\mathrm{C} 21-\mathrm{H} 21 \mathrm{~B}$ & 108.5 \\
\hline $\mathrm{C} 29-\mathrm{N} 4-\mathrm{N} 3$ & $120.51(11)$ & $\mathrm{N} 2-\mathrm{C} 21-\mathrm{C} 20$ & $114.97(11)$ \\
\hline $\mathrm{C} 5-\mathrm{N} 1-\mathrm{C} 4$ & $119.81(10)$ & $\mathrm{H} 21 \mathrm{~A}-\mathrm{C} 21-\mathrm{H} 21 \mathrm{~B}$ & 107.5 \\
\hline $\mathrm{C} 5-\mathrm{N} 1-\mathrm{C} 2$ & $121.79(11)$ & $\mathrm{C} 20-\mathrm{C} 21-\mathrm{H} 21 \mathrm{~A}$ & 108.5 \\
\hline $\mathrm{C} 2-\mathrm{N} 1-\mathrm{C} 4$ & $117.32(10)$ & $\mathrm{C} 20-\mathrm{C} 21-\mathrm{H} 21 \mathrm{~B}$ & 108.5 \\
\hline $\mathrm{C} 22-\mathrm{C} 27-\mathrm{C} 28$ & $109.72(10)$ & $\mathrm{C} 35-\mathrm{C} 30-\mathrm{C} 29$ & $122.63(12)$ \\
\hline
\end{tabular}




\begin{tabular}{|c|c|}
\hline $\mathrm{C} 22-\mathrm{C} 27-\mathrm{C} 26$ & $121.67(12)$ \\
\hline $\mathrm{C} 26-\mathrm{C} 27-\mathrm{C} 28$ & $128.59(11)$ \\
\hline $\mathrm{C} 13-\mathrm{C} 12-\mathrm{C} 11$ & $122.36(10)$ \\
\hline $\mathrm{C} 13-\mathrm{C} 12-\mathrm{C} 14$ & $115.90(11)$ \\
\hline $\mathrm{C} 14-\mathrm{C} 12-\mathrm{C} 11$ & $121.66(10)$ \\
\hline $\mathrm{O} 1-\mathrm{C} 9-\mathrm{C} 8$ & $123.28(10)$ \\
\hline $\mathrm{O} 1-\mathrm{C} 9-\mathrm{C} 10$ & $114.06(10)$ \\
\hline $\mathrm{C} 10-\mathrm{C} 9-\mathrm{C} 8$ & $122.65(11)$ \\
\hline $\mathrm{C} 27-\mathrm{C} 22-\mathrm{C} 11$ & $110.76(10)$ \\
\hline $\mathrm{C} 27-\mathrm{C} 22-\mathrm{C} 23$ & $120.92(11)$ \\
\hline $\mathrm{C} 23-\mathrm{C} 22-\mathrm{C} 11$ & $128.22(11)$ \\
\hline $\mathrm{C} 9-\mathrm{C} 8-\mathrm{C} 11$ & $122.00(11)$ \\
\hline $\mathrm{C} 9-\mathrm{C} 8-\mathrm{C} 7$ & $116.08(11)$ \\
\hline $\mathrm{C} 7-\mathrm{C} 8-\mathrm{C} 11$ & $121.92(10)$ \\
\hline $\mathrm{O} 1-\mathrm{C} 13-\mathrm{C} 12$ & $123.16(11)$ \\
\hline $\mathrm{O} 1-\mathrm{C} 13-\mathrm{C} 17$ & $114.14(10)$ \\
\hline $\mathrm{C} 12-\mathrm{C} 13-\mathrm{C} 17$ & $122.71(11)$ \\
\hline $\mathrm{C} 13-\mathrm{C} 17-\mathrm{H} 17$ & 119.5 \\
\hline $\mathrm{C} 13-\mathrm{C} 17-\mathrm{C} 16$ & $121.01(11)$ \\
\hline $\mathrm{C} 16-\mathrm{C} 17-\mathrm{H} 17$ & 119.5 \\
\hline $\mathrm{O} 2-\mathrm{C} 28-\mathrm{N} 3$ & $126.36(12)$ \\
\hline $\mathrm{O} 2-\mathrm{C} 28-\mathrm{C} 27$ & $128.73(11)$ \\
\hline $\mathrm{N} 3-\mathrm{C} 28-\mathrm{C} 27$ & $104.91(10)$ \\
\hline $\mathrm{N} 2-\mathrm{C} 16-\mathrm{C} 17$ & $121.29(11)$ \\
\hline $\mathrm{N} 2-\mathrm{C} 16-\mathrm{C} 15$ & $121.91(11)$ \\
\hline $\mathrm{C} 17-\mathrm{C} 16-\mathrm{C} 15$ & $116.80(11)$ \\
\hline $\mathrm{C} 9-\mathrm{C} 10-\mathrm{H} 10$ & 119.6 \\
\hline $\mathrm{C} 9-\mathrm{C} 10-\mathrm{C} 5$ & $120.88(11)$ \\
\hline $\mathrm{C} 5-\mathrm{C} 10-\mathrm{H} 10$ & 119.6 \\
\hline $\mathrm{N} 3-\mathrm{C} 11-\mathrm{C} 12$ & $109.86(9)$ \\
\hline $\mathrm{N} 3-\mathrm{C} 11-\mathrm{C} 22$ & $99.47(9)$ \\
\hline $\mathrm{N} 3-\mathrm{C} 11-\mathrm{C} 8$ & $110.89(9)$ \\
\hline $\mathrm{C} 12-\mathrm{C} 11-\mathrm{C} 22$ & $114.63(10)$ \\
\hline $\mathrm{C} 12-\mathrm{C} 11-\mathrm{C} 8$ & $110.56(9)$ \\
\hline $\mathrm{C} 8-\mathrm{C} 11-\mathrm{C} 22$ & $110.96(9)$ \\
\hline C8-C7-H7 & 118.6 \\
\hline $\mathrm{C} 6-\mathrm{C} 7-\mathrm{C} 8$ & $122.85(11)$ \\
\hline $\mathrm{C} 6-\mathrm{C} 7-\mathrm{H} 7$ & 118.6 \\
\hline $\mathrm{N} 1-\mathrm{C} 5-\mathrm{C} 10$ & $120.35(11)$ \\
\hline $\mathrm{N} 1-\mathrm{C} 5-\mathrm{C} 6$ & $122.44(11)$ \\
\hline $\mathrm{C} 10-\mathrm{C} 5-\mathrm{C} 6$ & $117.20(11)$ \\
\hline $\mathrm{C} 7-\mathrm{C} 6-\mathrm{C} 5$ & $120.31(11)$ \\
\hline $\mathrm{C} 7-\mathrm{C} 6-\mathrm{H} 6$ & 119.8 \\
\hline $\mathrm{C} 5-\mathrm{C} 6-\mathrm{H} 6$ & 119.8 \\
\hline $\mathrm{C} 23-\mathrm{C} 24-\mathrm{H} 24$ & 119.4 \\
\hline $\mathrm{C} 25-\mathrm{C} 24-\mathrm{H} 24$ & 119.4 \\
\hline $\mathrm{C} 25-\mathrm{C} 24-\mathrm{C} 23$ & $121.21(12)$ \\
\hline $\mathrm{C} 22-\mathrm{C} 23-\mathrm{C} 24$ & $117.65(11)$ \\
\hline
\end{tabular}

\begin{tabular}{|c|c|}
\hline $\mathrm{C} 31-\mathrm{C} 30-\mathrm{C} 29$ & $118.74(13)$ \\
\hline $\mathrm{C} 31-\mathrm{C} 30-\mathrm{C} 35$ & $118.62(13)$ \\
\hline $\mathrm{N} 1-\mathrm{C} 4-\mathrm{H} 4 \mathrm{~A}$ & 108.9 \\
\hline $\mathrm{N} 1-\mathrm{C} 4-\mathrm{H} 4 \mathrm{~B}$ & 108.9 \\
\hline $\mathrm{N} 1-\mathrm{C} 4-\mathrm{C} 3$ & $113.50(11)$ \\
\hline $\mathrm{H} 4 \mathrm{~A}-\mathrm{C} 4-\mathrm{H} 4 \mathrm{~B}$ & 107.7 \\
\hline $\mathrm{C} 3-\mathrm{C} 4-\mathrm{H} 4 \mathrm{~A}$ & 108.9 \\
\hline $\mathrm{C} 3-\mathrm{C} 4-\mathrm{H} 4 \mathrm{~B}$ & 108.9 \\
\hline $\mathrm{N} 2-\mathrm{C} 19-\mathrm{H} 19 \mathrm{~A}$ & 108.7 \\
\hline $\mathrm{N} 2-\mathrm{C} 19-\mathrm{H} 19 \mathrm{~B}$ & 108.7 \\
\hline $\mathrm{N} 2-\mathrm{C} 19-\mathrm{C} 18$ & $114.24(11)$ \\
\hline H19A-C19-H19B & 107.6 \\
\hline $\mathrm{C} 18-\mathrm{C} 19-\mathrm{H} 19 \mathrm{~A}$ & 108.7 \\
\hline $\mathrm{C} 18-\mathrm{C} 19-\mathrm{H} 19 \mathrm{~B}$ & 108.7 \\
\hline $\mathrm{N} 1-\mathrm{C} 2-\mathrm{H} 2 \mathrm{~A}$ & 108.5 \\
\hline $\mathrm{N} 1-\mathrm{C} 2-\mathrm{H} 2 \mathrm{~B}$ & 108.5 \\
\hline $\mathrm{N} 1-\mathrm{C} 2-\mathrm{C} 1$ & $115.10(11)$ \\
\hline $\mathrm{H} 2 \mathrm{~A}-\mathrm{C} 2-\mathrm{H} 2 \mathrm{~B}$ & 107.5 \\
\hline $\mathrm{C} 1-\mathrm{C} 2-\mathrm{H} 2 \mathrm{~A}$ & 108.5 \\
\hline $\mathrm{C} 1-\mathrm{C} 2-\mathrm{H} 2 \mathrm{~B}$ & 108.5 \\
\hline $\mathrm{O} 3-\mathrm{C} 35-\mathrm{C} 30$ & $122.46(12)$ \\
\hline $\mathrm{O} 3-\mathrm{C} 35-\mathrm{C} 34$ & $117.59(14)$ \\
\hline $\mathrm{C} 34-\mathrm{C} 35-\mathrm{C} 30$ & $119.94(14)$ \\
\hline $\mathrm{C} 4-\mathrm{C} 3-\mathrm{H} 3 \mathrm{~A}$ & 109.5 \\
\hline $\mathrm{C} 4-\mathrm{C} 3-\mathrm{H} 3 \mathrm{~B}$ & 109.5 \\
\hline $\mathrm{C} 4-\mathrm{C} 3-\mathrm{H} 3 \mathrm{C}$ & 109.5 \\
\hline $\mathrm{H} 3 \mathrm{~A}-\mathrm{C} 3-\mathrm{H} 3 \mathrm{~B}$ & 109.5 \\
\hline $\mathrm{H} 3 \mathrm{~A}-\mathrm{C} 3-\mathrm{H} 3 \mathrm{C}$ & 109.5 \\
\hline $\mathrm{H} 3 \mathrm{~B}-\mathrm{C} 3-\mathrm{H} 3 \mathrm{C}$ & 109.5 \\
\hline $\mathrm{C} 19-\mathrm{C} 18-\mathrm{H} 18 \mathrm{~A}$ & 109.5 \\
\hline $\mathrm{C} 19-\mathrm{C} 18-\mathrm{H} 18 \mathrm{~B}$ & 109.5 \\
\hline $\mathrm{C} 19-\mathrm{C} 18-\mathrm{H} 18 \mathrm{C}$ & 109.5 \\
\hline $\mathrm{H} 18 \mathrm{~A}-\mathrm{C} 18-\mathrm{H} 18 \mathrm{~B}$ & 109.5 \\
\hline $\mathrm{H} 18 \mathrm{~A}-\mathrm{C} 18-\mathrm{H} 18 \mathrm{C}$ & 109.5 \\
\hline $\mathrm{H} 18 \mathrm{~B}-\mathrm{C} 18-\mathrm{H} 18 \mathrm{C}$ & 109.5 \\
\hline $\mathrm{C} 21-\mathrm{C} 20-\mathrm{H} 20 \mathrm{~A}$ & 109.5 \\
\hline $\mathrm{C} 21-\mathrm{C} 20-\mathrm{H} 20 \mathrm{~B}$ & 109.5 \\
\hline $\mathrm{C} 21-\mathrm{C} 20-\mathrm{H} 20 \mathrm{C}$ & 109.5 \\
\hline $\mathrm{H} 20 \mathrm{~A}-\mathrm{C} 20-\mathrm{H} 20 \mathrm{~B}$ & 109.5 \\
\hline $\mathrm{H} 20 \mathrm{~A}-\mathrm{C} 20-\mathrm{H} 20 \mathrm{C}$ & 109.5 \\
\hline $\mathrm{H} 20 \mathrm{~B}-\mathrm{C} 20-\mathrm{H} 20 \mathrm{C}$ & 109.5 \\
\hline $\mathrm{C} 2-\mathrm{C} 1-\mathrm{H} 1 \mathrm{~A}$ & 109.5 \\
\hline $\mathrm{C} 2-\mathrm{C} 1-\mathrm{H} 1 \mathrm{~B}$ & 109.5 \\
\hline $\mathrm{C} 2-\mathrm{C} 1-\mathrm{H} 1 \mathrm{C}$ & 109.5 \\
\hline $\mathrm{H} 1 \mathrm{~A}-\mathrm{C} 1-\mathrm{H} 1 \mathrm{~B}$ & 109.5 \\
\hline $\mathrm{H} 1 \mathrm{~A}-\mathrm{C} 1-\mathrm{H} 1 \mathrm{C}$ & 109.5 \\
\hline $\mathrm{H} 1 \mathrm{~B}-\mathrm{C} 1-\mathrm{H} 1 \mathrm{C}$ & 109.5 \\
\hline $\mathrm{C} 30-\mathrm{C} 31-\mathrm{H} 31$ & 119.5 \\
\hline
\end{tabular}




\begin{tabular}{|c|c|c|c|}
\hline $\mathrm{C} 22-\mathrm{C} 23-\mathrm{H} 23$ & 121.2 & $\mathrm{C} 32-\mathrm{C} 31-\mathrm{C} 30$ & $120.98(16)$ \\
\hline $\mathrm{C} 24-\mathrm{C} 23-\mathrm{H} 23$ & 121.2 & $\mathrm{C} 32-\mathrm{C} 31-\mathrm{H} 31$ & 119.5 \\
\hline $\mathrm{C} 16-\mathrm{C} 15-\mathrm{H} 15$ & 119.7 & $\mathrm{C} 31-\mathrm{C} 32-\mathrm{H} 32$ & 120.1 \\
\hline $\mathrm{C} 14-\mathrm{C} 15-\mathrm{C} 16$ & $120.59(11)$ & $\mathrm{C} 31-\mathrm{C} 32-\mathrm{C} 33$ & $119.70(15)$ \\
\hline $\mathrm{C} 14-\mathrm{C} 15-\mathrm{H} 15$ & 119.7 & $\mathrm{C} 33-\mathrm{C} 32-\mathrm{H} 32$ & 120.1 \\
\hline $\mathrm{C} 27-\mathrm{C} 26-\mathrm{H} 26$ & 121.2 & $\mathrm{C} 35-\mathrm{C} 34-\mathrm{H} 34$ & 120.1 \\
\hline $\mathrm{C} 25-\mathrm{C} 26-\mathrm{C} 27$ & $117.57(12)$ & $\mathrm{C} 33-\mathrm{C} 34-\mathrm{C} 35$ & $119.83(16)$ \\
\hline $\mathrm{C} 25-\mathrm{C} 26-\mathrm{H} 26$ & 121.2 & $\mathrm{C} 33-\mathrm{C} 34-\mathrm{H} 34$ & 120.1 \\
\hline $\mathrm{C} 12-\mathrm{C} 14-\mathrm{H} 14$ & 118.5 & $\mathrm{C} 32-\mathrm{C} 33-\mathrm{H} 33$ & 119.5 \\
\hline $\mathrm{C} 15-\mathrm{C} 14-\mathrm{C} 12$ & $122.99(11)$ & $\mathrm{C} 34-\mathrm{C} 33-\mathrm{C} 32$ & $120.91(14)$ \\
\hline $\mathrm{C} 15-\mathrm{C} 14-\mathrm{H} 14$ & 118.5 & $\mathrm{C} 34-\mathrm{C} 33-\mathrm{H} 33$ & 119.5 \\
\hline $\mathrm{O} 1-\mathrm{C} 9-\mathrm{C} 8-\mathrm{C} 11$ & $0.75(17)$ & $\mathrm{C} 10-\mathrm{C} 9-\mathrm{C} 8-\mathrm{C} 11$ & $-178.13(11)$ \\
\hline $\mathrm{O} 1-\mathrm{C} 9-\mathrm{C} 8-\mathrm{C} 7$ & $179.83(10)$ & $\mathrm{C} 10-\mathrm{C} 9-\mathrm{C} 8-\mathrm{C} 7$ & $0.94(17)$ \\
\hline $\mathrm{O} 1-\mathrm{C} 9-\mathrm{C} 10-\mathrm{C} 5$ & $-178.87(10)$ & $\mathrm{C} 10-\mathrm{C} 5-\mathrm{C} 6-\mathrm{C} 7$ & $2.22(18)$ \\
\hline $\mathrm{O} 1-\mathrm{C} 13-\mathrm{C} 17-\mathrm{C} 16$ & $179.34(10)$ & $\mathrm{C} 11-\mathrm{N} 3-\mathrm{N} 4-\mathrm{C} 29$ & $168.12(11)$ \\
\hline $\mathrm{O} 3-\mathrm{C} 35-\mathrm{C} 34-\mathrm{C} 33$ & $179.94(14)$ & $\mathrm{C} 11-\mathrm{N} 3-\mathrm{C} 28-\mathrm{O} 2$ & $175.66(11)$ \\
\hline $\mathrm{N} 3-\mathrm{N} 4-\mathrm{C} 29-\mathrm{C} 30$ & $175.92(11)$ & $\mathrm{C} 11-\mathrm{N} 3-\mathrm{C} 28-\mathrm{C} 27$ & $-4.11(13)$ \\
\hline $\mathrm{N} 2-\mathrm{C} 16-\mathrm{C} 15-\mathrm{C} 14$ & $179.21(11)$ & $\mathrm{C} 11-\mathrm{C} 12-\mathrm{C} 13-\mathrm{O} 1$ & $3.95(18)$ \\
\hline $\mathrm{N} 4-\mathrm{N} 3-\mathrm{C} 28-\mathrm{O} 2$ & $10.6(2)$ & $\mathrm{C} 11-\mathrm{C} 12-\mathrm{C} 13-\mathrm{C} 17$ & $-176.23(11)$ \\
\hline $\mathrm{N} 4-\mathrm{N} 3-\mathrm{C} 28-\mathrm{C} 27$ & $-169.16(11)$ & $\mathrm{C} 11-\mathrm{C} 12-\mathrm{C} 14-\mathrm{C} 15$ & $176.21(11)$ \\
\hline $\mathrm{N} 4-\mathrm{N} 3-\mathrm{C} 11-\mathrm{C} 12$ & $-66.11(12)$ & $\mathrm{C} 11-\mathrm{C} 22-\mathrm{C} 23-\mathrm{C} 24$ & $173.34(11)$ \\
\hline N4-N3-C11-C22 & $173.25(9)$ & $\mathrm{C} 11-\mathrm{C} 8-\mathrm{C} 7-\mathrm{C} 6$ & $178.70(11)$ \\
\hline N4-N3-C11-C8 & $56.40(13)$ & $\mathrm{C} 7-\mathrm{C} 8-\mathrm{C} 11-\mathrm{N} 3$ & $56.81(14)$ \\
\hline $\mathrm{N} 4-\mathrm{C} 29-\mathrm{C} 30-\mathrm{C} 35$ & $-3.20(19)$ & $\mathrm{C} 7-\mathrm{C} 8-\mathrm{C} 11-\mathrm{C} 12$ & $178.91(10)$ \\
\hline $\mathrm{N} 4-\mathrm{C} 29-\mathrm{C} 30-\mathrm{C} 31$ & $178.18(12)$ & $\mathrm{C} 7-\mathrm{C} 8-\mathrm{C} 11-\mathrm{C} 22$ & $-52.75(15)$ \\
\hline $\mathrm{N} 1-\mathrm{C} 5-\mathrm{C} 6-\mathrm{C} 7$ & $-176.72(12)$ & $\mathrm{C} 5-\mathrm{N} 1-\mathrm{C} 4-\mathrm{C} 3$ & $65.09(16)$ \\
\hline $\mathrm{C} 27-\mathrm{C} 22-\mathrm{C} 11-\mathrm{N} 3$ & $-5.88(12)$ & $\mathrm{C} 5-\mathrm{N} 1-\mathrm{C} 2-\mathrm{C} 1$ & $-86.26(15)$ \\
\hline $\mathrm{C} 27-\mathrm{C} 22-\mathrm{C} 11-\mathrm{C} 12$ & $-122.98(11)$ & $\mathrm{C} 23-\mathrm{C} 22-\mathrm{C} 11-\mathrm{N} 3$ & $177.66(11)$ \\
\hline $\mathrm{C} 27-\mathrm{C} 22-\mathrm{C} 11-\mathrm{C} 8$ & $110.92(11)$ & $\mathrm{C} 23-\mathrm{C} 22-\mathrm{C} 11-\mathrm{C} 12$ & $60.56(16)$ \\
\hline $\mathrm{C} 27-\mathrm{C} 22-\mathrm{C} 23-\mathrm{C} 24$ & $-2.80(17)$ & $\mathrm{C} 23-\mathrm{C} 22-\mathrm{C} 11-\mathrm{C} 8$ & $-65.54(15)$ \\
\hline $\mathrm{C} 27-\mathrm{C} 26-\mathrm{C} 25-\mathrm{C} 24$ & $-1.80(18)$ & $\mathrm{C} 23-\mathrm{C} 24-\mathrm{C} 25-\mathrm{C} 26$ & $1.20(19)$ \\
\hline $\mathrm{C} 12-\mathrm{C} 13-\mathrm{C} 17-\mathrm{C} 16$ & $-0.50(18)$ & $\mathrm{C} 26-\mathrm{C} 27-\mathrm{C} 22-\mathrm{C} 11$ & $-174.51(11)$ \\
\hline $\mathrm{C} 9-\mathrm{O} 1-\mathrm{C} 13-\mathrm{C} 12$ & $-5.36(16)$ & $\mathrm{C} 26-\mathrm{C} 27-\mathrm{C} 22-\mathrm{C} 23$ & $2.25(18)$ \\
\hline $\mathrm{C} 9-\mathrm{O} 1-\mathrm{C} 13-\mathrm{C} 17$ & $174.80(10)$ & $\mathrm{C} 26-\mathrm{C} 27-\mathrm{C} 28-\mathrm{O} 2$ & $-1.4(2)$ \\
\hline $\mathrm{C} 9-\mathrm{C} 8-\mathrm{C} 11-\mathrm{N} 3$ & $-124.17(12)$ & $\mathrm{C} 26-\mathrm{C} 27-\mathrm{C} 28-\mathrm{N} 3$ & $178.35(12)$ \\
\hline $\mathrm{C} 9-\mathrm{C} 8-\mathrm{C} 11-\mathrm{C} 12$ & $-2.06(15)$ & $\mathrm{C} 14-\mathrm{C} 12-\mathrm{C} 13-\mathrm{O} 1$ & $-179.16(11)$ \\
\hline $\mathrm{C} 9-\mathrm{C} 8-\mathrm{C} 11-\mathrm{C} 22$ & $126.28(12)$ & $\mathrm{C} 14-\mathrm{C} 12-\mathrm{C} 13-\mathrm{C} 17$ & $0.67(17)$ \\
\hline $\mathrm{C} 9-\mathrm{C} 8-\mathrm{C} 7-\mathrm{C} 6$ & $-0.38(18)$ & $\mathrm{C} 14-\mathrm{C} 12-\mathrm{C} 11-\mathrm{N} 3$ & $-54.17(14)$ \\
\hline $\mathrm{C} 9-\mathrm{C} 10-\mathrm{C} 5-\mathrm{N} 1$ & $177.28(11)$ & $\mathrm{C} 14-\mathrm{C} 12-\mathrm{C} 11-\mathrm{C} 22$ & $56.81(15)$ \\
\hline $\mathrm{C} 9-\mathrm{C} 10-\mathrm{C} 5-\mathrm{C} 6$ & $-1.68(17)$ & $\mathrm{C} 14-\mathrm{C} 12-\mathrm{C} 11-\mathrm{C} 8$ & $-176.88(10)$ \\
\hline $\mathrm{C} 22-\mathrm{C} 27-\mathrm{C} 28-\mathrm{O} 2$ & $-179.82(12)$ & $\mathrm{C} 25-\mathrm{C} 24-\mathrm{C} 23-\mathrm{C} 22$ & $1.12(18)$ \\
\hline $\mathrm{C} 22-\mathrm{C} 27-\mathrm{C} 28-\mathrm{N} 3$ & $-0.05(13)$ & $\mathrm{C} 29-\mathrm{C} 30-\mathrm{C} 35-\mathrm{O} 3$ & $1.0(2)$ \\
\hline $\mathrm{C} 22-\mathrm{C} 27-\mathrm{C} 26-\mathrm{C} 25$ & $0.11(18)$ & $\mathrm{C} 29-\mathrm{C} 30-\mathrm{C} 35-\mathrm{C} 34$ & $-178.41(13)$ \\
\hline $\mathrm{C} 8-\mathrm{C} 9-\mathrm{C} 10-\mathrm{C} 5$ & $0.11(18)$ & $\mathrm{C} 29-\mathrm{C} 30-\mathrm{C} 31-\mathrm{C} 32$ & $179.28(13)$ \\
\hline $\mathrm{C} 8-\mathrm{C} 7-\mathrm{C} 6-\mathrm{C} 5$ & $-1.23(19)$ & $\mathrm{C} 21-\mathrm{N} 2-\mathrm{C} 16-\mathrm{C} 17$ & $0.60(17)$ \\
\hline $\mathrm{C} 13-\mathrm{O} 1-\mathrm{C} 9-\mathrm{C} 8$ & $2.99(16)$ & $\mathrm{C} 21-\mathrm{N} 2-\mathrm{C} 16-\mathrm{C} 15$ & $-178.94(11)$ \\
\hline $\mathrm{C} 13-\mathrm{O} 1-\mathrm{C} 9-\mathrm{C} 10$ & $-178.03(10)$ & $\mathrm{C} 21-\mathrm{N} 2-\mathrm{C} 19-\mathrm{C} 18$ & $-102.27(13)$ \\
\hline
\end{tabular}




$\begin{array}{ll}\mathrm{C} 13-\mathrm{C} 12-\mathrm{C} 11-\mathrm{N} 3 & 122.54(12) \\ \mathrm{C} 13-\mathrm{C} 12-\mathrm{C} 11-\mathrm{C} 22 & -126.47(12) \\ \mathrm{C} 13-\mathrm{C} 12-\mathrm{C} 11-\mathrm{C} 8 & -0.16(15) \\ \mathrm{C} 13-\mathrm{C} 12-\mathrm{C} 14-\mathrm{C} 15 & -0.71(18) \\ \mathrm{C} 13-\mathrm{C} 17-\mathrm{C} 16-\mathrm{N} 2 & -179.25(11) \\ \mathrm{C} 13-\mathrm{C} 17-\mathrm{C} 16-\mathrm{C} 15 & 0.31(17) \\ \mathrm{C} 17-\mathrm{C} 16-\mathrm{C} 15-\mathrm{C} 14 & -0.34(18) \\ \mathrm{C} 28-\mathrm{N} 3-\mathrm{N} 4-\mathrm{C} 29 & -26.88(18) \\ \mathrm{C} 28-\mathrm{N} 3-\mathrm{C} 11-\mathrm{C} 12 & 126.76(11) \\ \mathrm{C} 28-\mathrm{N} 3-\mathrm{C} 11-\mathrm{C} 22 & 6.13(12) \\ \mathrm{C} 28-\mathrm{N} 3-\mathrm{C} 11-\mathrm{C} 8 & -110.73(11) \\ \mathrm{C} 28-\mathrm{C} 27-\mathrm{C} 22-\mathrm{C} 11 & 4.02(13) \\ \mathrm{C} 28-\mathrm{C} 27-\mathrm{C} 22-\mathrm{C} 23 & -179.22(10) \\ \mathrm{C} 28-\mathrm{C} 27-\mathrm{C} 26-\mathrm{C} 25 & -178.12(12) \\ \mathrm{C} 16-\mathrm{N} 2-\mathrm{C} 21-\mathrm{C} 20 & -79.52(15) \\ \mathrm{C} 16-\mathrm{N} 2-\mathrm{C} 19-\mathrm{C} 18 & 73.76(15) \\ \mathrm{C} 16-\mathrm{C} 15-\mathrm{C} 14-\mathrm{C} 12 & 0.57(19)\end{array}$

$$
\mathrm{C} 30-\mathrm{C} 35-\mathrm{C} 34-\mathrm{C} 33
$$$$
\mathrm{C} 30-\mathrm{C} 31-\mathrm{C} 32-\mathrm{C} 33
$$$$
\mathrm{C} 4-\mathrm{N} 1-\mathrm{C} 5-\mathrm{C} 10
$$$$
\mathrm{C} 4-\mathrm{N} 1-\mathrm{C} 5-\mathrm{C} 6
$$$$
\mathrm{C} 4-\mathrm{N} 1-\mathrm{C} 2-\mathrm{C} 1
$$$$
\mathrm{C} 19-\mathrm{N} 2-\mathrm{C} 16-\mathrm{C} 17
$$$$
\mathrm{C} 19-\mathrm{N} 2-\mathrm{C} 16-\mathrm{C} 15
$$$$
\mathrm{C} 19-\mathrm{N} 2-\mathrm{C} 21-\mathrm{C} 20
$$$$
\mathrm{C} 2-\mathrm{N} 1-\mathrm{C} 5-\mathrm{C} 10
$$$$
\mathrm{C} 2-\mathrm{N} 1-\mathrm{C} 5-\mathrm{C} 6
$$$$
\mathrm{C} 2-\mathrm{N} 1-\mathrm{C} 4-\mathrm{C} 3
$$$$
\mathrm{C} 35-\mathrm{C} 30-\mathrm{C} 31-\mathrm{C} 32
$$$$
\mathrm{C} 35-\mathrm{C} 34-\mathrm{C} 33-\mathrm{C} 32
$$$$
\mathrm{C} 31-\mathrm{C} 30-\mathrm{C} 35-\mathrm{O} 3
$$$$
\mathrm{C} 31-\mathrm{C} 30-\mathrm{C} 35-\mathrm{C} 34
$$$$
\mathrm{C} 31-\mathrm{C} 32-\mathrm{C} 33-\mathrm{C} 34
$$

$-0.6(2)$

$-1.0(2)$

20.76 (18)

$-160.34(12)$

81.84 (15)

$-175.33(11)$

$5.13(17)$

$96.50(13)$

$-171.43(11)$

7.48 (18)

$-103.26(13)$

$0.6(2)$

$0.2(2)$

179.64 (12)

$0.2(2)$

$0.6(2)$

Hydrogen-bond geometry $\left(\AA,{ }^{\circ}\right)$

$\mathrm{Cg}$ is the centroid of the $\mathrm{C} 22-\mathrm{C} 27$ ring.

\begin{tabular}{lllll}
\hline$D-\mathrm{H} \cdots A$ & $D-\mathrm{H}$ & $\mathrm{H} \cdots A$ & $D \cdots A$ & $D-\mathrm{H} \cdots A$ \\
\hline $\mathrm{C} 31-\mathrm{H} 31 \cdots \mathrm{O} 3^{\mathrm{i}}$ & 0.95 & 2.77 & $3.4737(19)$ & 131 \\
$\mathrm{O} 3-\mathrm{H} 3 \cdots \mathrm{N} 4$ & $1.02(3)$ & $1.72(2)$ & $2.6276(15)$ & $145(2)$ \\
$\mathrm{C} 18-\mathrm{H} 18 A \cdots C g^{\mathrm{ii}}$ & 0.98 & 2.88 & $3.8191(15)$ & 161 \\
\hline
\end{tabular}

Symmetry codes: (i) $x,-y+3 / 2, z-1 / 2$; (ii) $-x+1,-y+1,-z$. 